OPEN ACCESS

Edited by: Julia G. Prado,

IrsiCaixa, Spain

Reviewed by:

Susan Zolla-Pazner,

Icahn School of Medicine at Mount

Sinai, United States

Riccardo Gavioli,

University of Ferrara, Italy

${ }^{*}$ Correspondence:

Ali A. Sultan

als2026@qatar-med.cornell.edu

Specialty section

This article was submitted to

Viral Immunology,

a section of the journal

Frontiers in Immunology

Received: 19 November 2020

Accepted: 26 January 2021

Published: 26 February 2021

Citation:

Triggle CR, Bansal D, Ding $H$, Islam MM, Farag EABA, Hadi HA and Sultan AA (2021) A Comprehensive

Review of Viral Characteristics,

Transmission, Pathophysiology,

Immune Response, and Management of SARS-CoV-2 and COVID-19 as a Basis for Controlling the Pandemic.

Front. Immunol. 12:631139.

doi: 10.3389/fimmu.2021.631139

\section{A Comprehensive Review of Viral Characteristics, Transmission, Pathophysiology, Immune Response, and Management of SARS-CoV-2 and COVID-19 as a Basis for Controlling the Pandemic}

Chris R. Triggle ${ }^{1}$, Devendra Bansal ${ }^{2}$, Hong Ding ${ }^{1}$, Md Mazharul Islam $^{3}$, Elmoubashar Abu Baker Abd Farag ${ }^{2}$, Hamad Abdel Hadi ${ }^{4}$ and Ali A. Sultan ${ }^{5 *}$

${ }^{1}$ Department of Pharmacology, Weill Cornell Medicine-Qatar, Education City, Qatar Foundation, Doha, Qatar, ${ }^{2}$ Department of Health Protection \& Communicable Diseases Control, Ministry of Public Health, Doha, Qatar, ${ }^{3}$ Department of Animal Resources, Ministry of Municipality and Environment, Doha, Qatar, ${ }^{4}$ Communicable Diseases Centre, Hamad Medical Corporations, Doha, Qatar, ${ }^{5}$ Department of Microbiology and Immunology, Weill Cornell Medicine, Cornell University, Doha, Qatar

COVID-19 emerged from China in December 2019 and during 2020 spread to every continent including Antarctica. The coronavirus, SARS-CoV-2, has been identified as the causative pathogen, and its spread has stretched the capacities of healthcare systems and negatively affected the global economy. This review provides an update on the virus, including the genome, the risks associated with the emergence of variants, mode of transmission, immune response, COVID-19 in children and the elderly, and advances made to contain, prevent and manage the disease. Although our knowledge of the mechanics of virus transmission and the immune response has been substantially demystified, concerns over reinfection, susceptibility of the elderly and whether asymptomatic children promote transmission remain unanswered. There are also uncertainties about the pathophysiology of COVID-19 and why there are variations in clinical presentations and why some patients suffer from long lasting symptoms - "the long haulers." To date, there are no significantly effective curative drugs for COVID19, especially after failure of hydroxychloroquine trials to produce positive results. The RNA polymerase inhibitor, remdesivir, facilitates recovery of severely infected cases but, unlike the anti-inflammatory drug, dexamethasone, does not reduce mortality. However, vaccine development witnessed substantial progress with several being approved in countries around the globe.

Keywords: SARS-CoV-2, COVID-19, immune response, pathophysiology, drugs, COVID vaccines, transmission 


\section{INTRODUCTION}

The highly infectious coronavirus disease 2019, COVID-19, is caused by the RNA virus, severe acute respiratory syndrome coronavirus 2 (SARS-CoV-2), which was first identified in Wuhan, China in December 2019 and declared a pandemic by the World Health Organization (WHO) in March 2020. By the end of 2020 COVID-19 had reached all continents including Antarctica sparing just a few Pacific Island nations, and daily increases can be monitored via accessing the Johns Hopkins Coronavirus Resource site (1). Consequently, the impact of the pandemic on healthcare is unprecedented stretching healthcare systems across the globe, as well as endangering healthcare professionals as one in seven has been infected (2). The swift identification and sequencing of the SARS-CoV-2 genome initiated a global program to develop vaccines as well as to investigate potential therapeutic agents. In this review we update our current knowledge of the genome structure of SARS-CoV-2 including mutational changes and implications on infectivity, transmission, pathophysiology, and host immune responses. We will discuss the impact of COVID-19 on the pediatric and elderly populations, assess the evidence for the effectiveness of therapeutics options, progress in the development of vaccines, and current regional public health measures to control the pandemic.

\section{ORIGIN AND TRANSMISSION OF SARS-COV-2}

\section{Origin of SARS-CoV-2}

Human epidemiological data links early spillover of SARS-CoV-2 to the Wuhan Seafood Market in China, where various livestock and species of wildlife and their products were sold (3). Most of the positive samples came from the Western part of the Huanan Seafood Market where animal facilities were located (4). In the absence of clear epidemiological evidence it was predicted that either the virus was introduced into the human population from an animal source from within the Huanan Seafood Market or alternatively an infected human could have introduced the virus into the market (5). Early reports were highly suggestive that SARS-CoV- 2 jumped from bats via animal reservoir transmission, similar to that for SARS-CoV and MERS$\mathrm{CoV}$ through civet cats and dromedary camels (4, 6-8). Based on the molecular similarities between SARS-CoV and the SARS$\mathrm{CoV}-2$, it can be assumed that the transmission route of the virus to humans involves an intermediate unidentified domestic, domesticated, or wild animal host (Figure 1). Coronaviruses are species-adapted where over time mutation of the viral genome can be adapted to new hosts, making transmission from one species to another rare. Nevertheless, some of the coronavirus species have shown a broad host range, such as SARS-CoV, MERS-CoV, and Bov-CoV (14). Although, coronavirus mutation rates are not as frequent compared to other viral families, RNA viruses are generally more susceptible to mutation compared to DNA viruses (15). Subsequently, with a significant mutation of the SARS-CoV-2 virus it could have been transmitted to humans through contact, handling or consumption of infected animals.

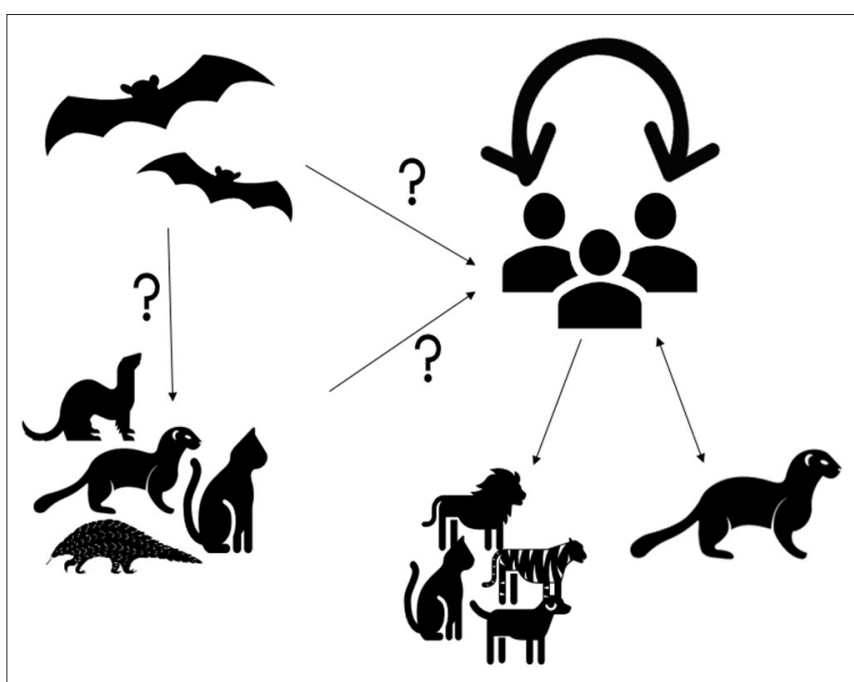

FIGURE 1 | Origin and dynamics of SARS-CoV-2. SARS-CoV-2 is suspected to originate from bats $(8,9)$. It is unclear if the virus is transmitted to humans directly from bats or via intermediate hosts such as cats, pangolins, ferrets, minks or other animals. Infection with SARS-CoV-2 in cats, dogs, tigers, and lions were suggested to originate from human carriers (10). SARS-CoV-2 transmission from humans to minks and from minks to humans was detected in the Netherlands and Denmark $(11,12)$. However, human to human transmission remains the main route of transmission during the current pandemic (13).

Genetic sequence data reveals that SARS-CoV-2 is a close relative of other species of coronaviruses found to be circulating in Rhinolophus bat (Horseshoe Bat) populations $(9,16)$. A 99\% sequence similarity was detected between coronaviruses from Malayan pangolin and SARS-CoV-2 $(4,17)$. It has also been suggested that SARS-CoV-2 may have been transmitted to humans from snakes (4). When Egyptian fruit bats were infected with SARS-CoV-2 in a laboratory settings, these animals did not show signs of disease, but were able to transmit the virus to others (18). Experimental infection studies have also shown that ferrets and domestic cats were susceptible to infection by SARS-CoV2 and could efficiently transmit the virus to uninfected animals (19-22). Other studies have shown that Golden Syrian hamsters, as well as cynomolgus and rhesus macaques, could be infected by SARS-CoV-2 and may show clinical signs $(23,24)$. Similarly, the Erasmus University Rotterdam research group found that rabbits are potentially susceptible (25). Dogs were also shown to be susceptible to the infection but appear to be less affected than ferrets or cats (19-21). Furthermore, previous natural infections with SARS-CoV-2 were detected in cats, dogs, lions, minks, and tigers (26-32). In addition, a new emerging strain of SARSCoV-2 has been identified in minks, which were exposed to infected humans (33). The discovery was made in Denmark where the variant was observed in 12 human cases and which has since been labeled as "cluster 5," with its genetic makeup yet to be fully understood (11). This information elucidates the notion that minks could serve as a reservoir for SARS-CoV-2 and pose a risk for a spill-over to human populations as reported in The Netherlands (34). It is not uncommon for human to 
animal transmission to occur which can lead to genetic mutations of the virus. As a consequence, the WHO has encouraged all countries to strengthen their biosafety and biosecurity measures to reduce the zoonotic risks of events in relation to SARSCoV-2, including infection prevention and control measures of farms and animal industry $(33,35)$. In January 2021, the WHO tasked an international scientific committee of experts in field of epidemiology and infectious diseases to investigate the origin of the COVID-19 pandemic in China using a scientific and transparent approach not only for identifying the origin of the current pandemic but for the future of global health security to manage emerging infectious threats (35).

\section{SARS-CoV-2 Transmission}

SARS-CoV-2 is a pneumotropic virus that spreads from person-to-person predominantly through respiratory secretions including droplets generated through coughing, sneezing or even via talking. Transmission via personal contact, contaminated surfaces or fomites also contributes, particularly in settings where non-pharmaceutical interventions (NPIs) such as hand hygiene, masks and appropriate social distancing are not consistently applied $(36,37)$. In indoor settings with inadequate ventilation SARS-CoV-2 remains highly infectious as aerosols potentially for hours and can travel for tens of meters before landing on surfaces, where the virus can survive for up to 6 days (38-40). Since the beginning of the pandemic various NPI mitigation measures have been implemented, albeit inconsistently, to hamper the spread of the disease, including contact tracing, avoidance of mass gathering and community lockdowns. The danger of airborne transmission calls for additional preventative measures such as social and occupational health measures to ensure that buildings are well-ventilated and not overcrowded. In early July 2020, 239 scientists from more than 30 countries submitted an open letter to the WHO urging the organization to highlight the potential high risk of an airborne spread (41).

\section{SARS-COV-2 GENOME STRUCTURE: ROLE IN INFECTIVITY AND VIRULENCE}

SARS-CoV-2 is a single-stranded, positive-sense, non-segmented enveloped RNA virus of $\sim 29.9 \mathrm{kB}$ in size with a diameter of 50-200 nm (42). Structurally, it has a double-layered lipid envelope, including spike (S) glycoprotein, envelope protein, membrane glycoprotein, and nucleocapsid protein $(43,44)$. The viral spike glycoprotein has a receptor-binding domain (RBD) for the interaction with host cell receptors (45). The membrane glycoprotein is responsible for the assembly of viral particles (46). The envelope protein is reported to play a role in pathogenesis as it interacts with the tight junction related protein, named; Protein Associated with Caenorhabditis elegans Lin-7 protein 1 (PALS1) (47). The nucleocapsid protein, which is a phosphoprotein, packs the viral genome into a ribonucleoprotein complex and plays a role in viral genome replication and the cell-signaling pathway (48).

The SARS-CoV-2 virus enters host cells via hijacking physiological ACE2 receptors where it uses the Spike (S) glycoprotein for their attachment (Figure 2) followed by internalization (49). The spike glycoprotein has two subunits, S1 and S2. The S1 subunit consists of the receptor-binding domain (RBD), which binds with the receptor-binding motif (RBM) of cell surface receptor, while the S2 subunit, mediates fusion with the host cell membrane $(50,51)$. The spike protein is cleaved by host proteases (located on S2 sub-unit) to make necessary conformational changes for membrane fusion $(50,52)$. The type II transmembrane serine protease (TMPRSS2) is the main host protease that mediates $S$ protein activation and initial viral entry into primary target cells $(53,54)$. Camostat mesylate, an inhibitor of serine protease TMPRSS2, blocks the entry of coronaviruses into the cell indicating the its important role in priming the $S$ glycoproteins thus initiating infection (54). Furin is another host protease, which plays an important role in cellular pathogenesis of COVID-19 (55) (Figure 3).

One of the most comprehensive approaches in understanding genetic determinants of viral virulence as well as identifying host specific immune adaptations, is the study of the evolution of the virus through whole genome sequencing (WGS). This advanced process resulted in rapid sequencing of thousands of SARS-CoV-2 genomic isolates from different parts of the world, following deciphering the foremost COVID-19 strain from China published in early January 2020 (56).

Mutational hot spots in the SARS-CoV-2 virus include non-structural proteins (NSPs): NSP2 and NSP3, S protein, and RNA-dependent RNA polymerase (RdRp) (57), and mutations in NSP2 and NSP3 proteins and S protein are key contributory factors in virulence and differentiation mechanisms of SARS-CoV-2 that affect how it spreads and evolves (58). Genomic analysis revealed that mutations in SARS-CoV-2 accumulate at a significantly slower rate when compared with other extensively studied RNA viruses such as influenza and HIV (59).

Structural sequencing analysis of SARS-CoV-1 spike glycoprotein and SARS-CoV-2 spike glycoprotein reveals 76\% amino-acid sequences homology $(55,60)$. Moreover, both SARS-CoV-1 and SARS-CoV-2 shares eight conserved binding positions and six semi-conserved positions in their $S$ protein domains $(55,61)$. Therefore, the binding efficiencies of the spike glycoproteins of both SARS-CoV-1 and SARS-CoV-2 are similar to each other, however, the conservation and semi-substitution in spike glycoprotein have somehow made the SARS-CoV-2 more adaptable to the ACE2 receptors, thereby enhancing transmission (55). Furthermore, using comparative genomic techniques, Gussow et al. identified important features that differentiate SARS-CoV-2 from SARS-CoV and MERS-CoV (62). These features include enhancement of the nuclear localization signals of the nucleocapsid proteins through which the spike glycoprotein inserts and appears to be associated with higher case fatalities as well as inter species transmission from animals to humans (63). Based on ongoing genome sequencing of SARS-CoV-2, multiple SARS-CoV-2 variants have been reported are circulating globally (64). Mutations of the spike proteins are of fundamental importance because of their role in host cell entry as well as being the main target 


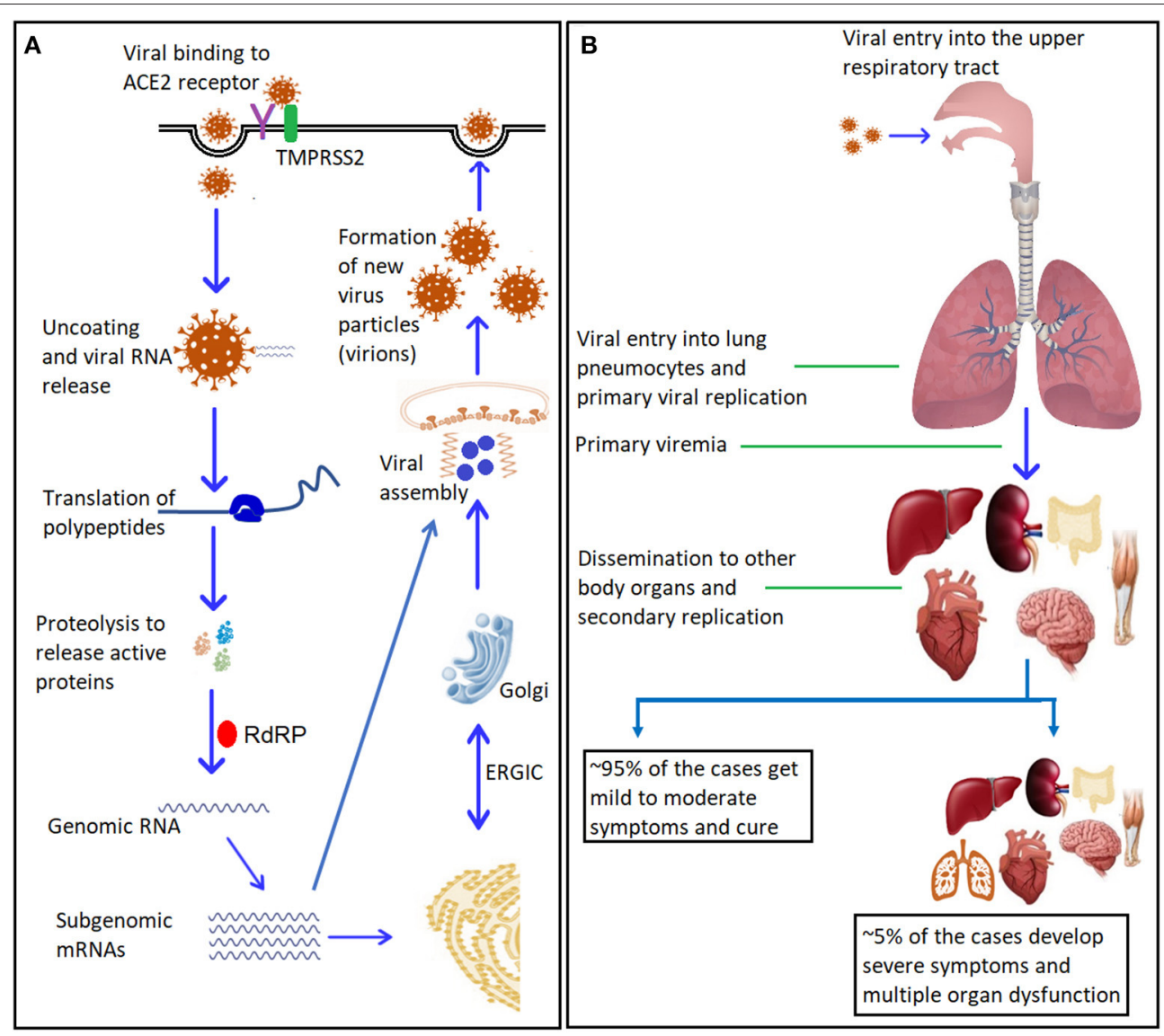

FIGURE 2 | SARS-CoV-2: mechanism of entry, replication, and dissemination. (A) Entry and replication of SARS-CoV-2 inside the host cells. The virus spike glycoprotein binds to the cellular receptor ACE2. This binding induces conformational changes at the receptor binding domain (RBD) that expose co-receptors to bind with transmembrane protease serine-2 (TMPRSS2), with the help of cellular endosomes it facilitates viral internalization via endocytosis. Internalization results in uncoating of viral genomic RNA into the cytoplasm. Genomic RNA binds to the host ribosome, which leads to formation of polyproteins that contain transcription complex, including the viral RNA-dependent RNA polymerase (RdRP). The RdRP generates viral genomic RNA and several subgenomic mRNAs, which will be translated into relevant viral proteins. The translated proteins translocate into endoplasmic reticulum (ER) membranes and transit through the ER-to-Golgi intermediate compartment (ERGIC), where interaction with encapsidated, newly produced genomic RNA results in budding into the lumen of secretory vesicular compartments. The newly formed viral particles (virions) are subsequently released out of the cells via exocytosis. (B) Viremia and dissemination into body organs: Initial replication takes place in the upper respiratory tract, followed by the migration of the virus to the lungs. A primary viremia occurs after establishment of infection and replication in the lung pneumocytes. This viremia disseminates the virus throughout the body via blood stream where another cycle of viral replication takes places and ensuing viremia leads to further dissemination (for more details and references see section SARS-CoV-2 Genome Structure: Role in Infectivity and Virulence and Replication Cycle and Pathophysiology of the review). ACE2, Angiotensin-converting enzyme 2; RdRP, RNA-dependent RNA polymerase. ER, Endoplasmic reticulum; ERGIC, ER-Golgi Intermediate Compartment.

for immune neutralizing antibodies and vaccine development. For instance, a change of an amino acid on spike protein from aspartate to glycine at position $614(\mathrm{D} 614 \mathrm{G})$ was first described in March 2020, and by June 2020 it had been reported worldwide. Although there was an initial concern that the D614G mutation confers enhanced transmission, this was subsequently refuted $(59,63)$. Several new variants emerged in the fall of 2020 , most notably:

a) A new variant of SARS-CoV-2 (coined VOC 202012/01 or B.1.1.7) emerged in late summer to early Autumn 2020 in United Kingdom $(65,66)$. This variant has since been detected in numerous countries around the world $(67,68)$ and has 17 mutations, eight of which are in the spike protein $(69,70)$. Based on mathematical models, calculations by the COVID19 Genomics UK consortium suggest that B.1.1.7 variant might be up to $70 \%$ more transmissible than the original virus $(67,71)$,

b) A non-related variant of SARS-CoV-2 (coined N501Y.V2 or B.1.351) emerged in South Africa independent from that in the UK variant, which bears mutational similarities to the latter (66). Cases attributed to this variant have been detected outside of South Africa (66). The N501Y.V2 variant seemed to improve the virus's binding abilities, which could lead to enhanced transmissibility (72), 


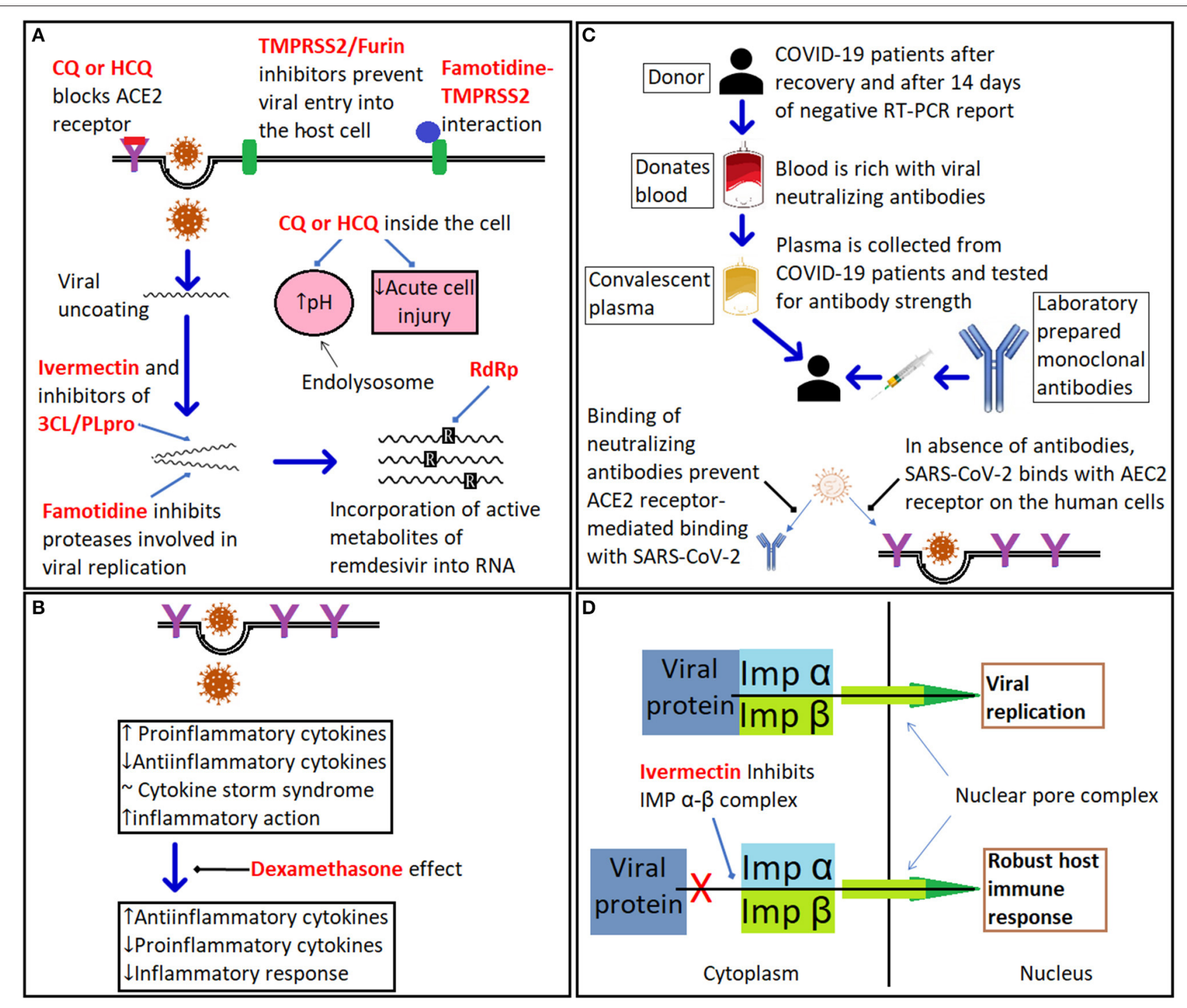

FIGURE 3 | The mechanism of action of different therapeutics against COVID-19. (A) illustrates the mode of action of drugs targeting COVID-19 including chloroquine (CQ) and hydroxychloroquine (HCQ), which have multiple putative sites of action: (i). ACE2 receptor for SARS-CoV-2; (ii). increasing the pH of the endolysosome; and (iii). suppression of the immune response. Sites of action of TMPRSS2 inhibitors such as camostat, famotidine, and furin inhibitors are shown; famotidine is also a putative inhibitor of the 3CL/PLpro proteases; ivermectin is a putative TMPRSS2 inhibitor that also inhibits the importin (IMP) $\alpha-\beta$ complex and viral replication; while remdesivir inhibits viral RNA polymerase. (B) Dexamethasone suppresses expression of pro-inflammatory cytokines. (C) Summary of role of convalescent plasma and monoclonal antibody therapy. (D) Ivermectin inhibits the heterodimeric importin (IMP) $\alpha / \beta$ complex via binding directly to IMP $\alpha$ preventing nuclear import of key viral proteins (for more details and references, see section COVID-19 therapeutics).

c) A third new distinct variant of SARS-CoV-2 emerged in Nigeria, which did not share any of the unique mutations of the aforementioned variants $(66,67,73)$.

Similar to other RNA viruses, SARS-CoV-2 is evolving and mutating all the time, thus such variants are completely expected, although coronaviruses in general tend to mutate more slowly. From recent reports current evidence suggests that the newly detected SARS-CoV-2 variant in the UK offers evolutional advantages in term of transmission rather than virulence (68, 74). While awaiting detailed confirmation, a pre-print article highlighted that an engineered SARS-CoV-2 with the N501Y mutation, one of many mutations present in the new emerging viral variants B.1.1.7 and 501.V2, can be neutralized by the sera of COVID-19 vaccine recipients (75).

As a consequence, the future course of the COVID-19 pandemic will be determined by the virological diversity, epidemiological spread as well as the clinical characteristics of these variants. Whether such variants confer biological advantages over the host will determine infectivity and virulence and ultimately the efficacy of vaccines as well as targeted therapies. 


\section{REPLICATION CYCLE AND PATHOPHYSIOLOGY}

The pathophysiological sequalae of infection with SARS-CoV-2 is illustrated in Figures 2A,B. The primary route of entry for SARS$\mathrm{CoV}-2$ is through the upper respiratory tract or facial mucosal surfaces. Viral particles gain access into cells by binding to ACE2 receptors followed by receptor-mediated endocytosis, similar to mechanisms used by the closely related virus, SARS-CoV (76). This entry mechanism has been confirmed experimentally when anti-ACE2 monoclonal antibodies were deployed into cell cultures blocking viral entry (77). Uncoating of viral genetic material and protein allows for the release of the RNA and translational proteins including RNA dependent polymerase followed by viral transcription and assembly and subsequent viral shedding to complete replication cycle (78).

In humans, the primary physiological function of ACE2 is to convert the peptides angiotensin I and II into angiotensin 19 and angiotensin 1-7, which provide protective cardiovascular functions through mechanisms that include vasodilatation and control of endothelial permeability (79). Infection with SARSCoV-2 results in a reduction in the levels of ACE2 and disruption in the Renin Angiotensin Aldosterone System (RAAS), which amplifies signaling through the angiotensin II pathway, resulting in potentially severe inflammatory and circulatory dysfunction (79). In addition to its expression in respiratory cells including upper airways, ACE2 receptors have also been isolated from the endothelium, gastrointestinal and renal tissues hence explaining the multisystem presentations (80). The comparatively high prevalence of COVID-19 in individuals with hypertension or diabetes raised the concern of the role of the ACE2 receptors in this vulnerable population particularly given that a significant proportion of them might be concomitantly treated with $\mathrm{ACE}$ inhibitors (ACEIs) or angiotensin II receptor blockers (ARBs). There was initial concern that the concomitant treatment of COVID-19 patients with ACEIs or ARBs would enhance ACE2 expression and hence susceptibility to infection and pathophysiological sequelae, but fortunately, this has not been supported by clinical evidence (28). Arguably, because of the beneficial effects of ACE2 mediated pathways in offsetting the pathophysiological effects of RAAS pathway activation and thereby providing cardiovascular and renal protection ARBs and ACEIs may prove beneficial in patients with COVID-19 (81). To address these questions, data from clinical trials to determine whether ACEIs, or ARBs, are beneficial in COVID-19 in both inpatient and outpatient settings (identifiers: NCT04311177, and NCT04312009, respectively) are expected during 2021.

Although the major clinical manifestations of COVID-19 were immediately identified as primarily a respiratory disease with multisystem involvement and spectra of symptoms, the distinct underlying mechanisms that lead extrapulmonary presentations of COVID-19 have not been fully established (82). A systematic review of 18 studies with an estimated cumulative 15,000 COVID-19 cases revealed that the prevalence was highest amongst patients with hypertension $(\sim 23 \%)$, diabetes $(\sim 11.5 \%)$, cardiovascular disease $(\mathrm{CVD})(\sim 10 \%)$ as well as chronic pulmonary and kidney diseases (83). Furthermore, a higher level of expression of ACE2 in adipose tissue together with a hyper inflammatory state prevalent in obese individuals could increase the risk of a cytokine storm and end organ damage (84).

While exposed patients can be asymptomatic or develop mild to moderate symptoms, around $20 \%$ suffer from severe disease that requires oxygen supplementation and, sometimes, critical care with ventilator support (85). There have been reports of long-term respiratory sequelae such as impairment of lung functions due to fibrosis, long-term neurological dysfunctions including variable loss of taste and olfactory senses, neuropathies, as well as memory dysfunction (82). From the histopathological examination of autopsy cases, destruction of alveolar structures denotes direct viral cytopathic effects (86). During the pandemic, it became apparent that arterial and venous thromboembolism are characteristic features of the disease indicating that endothelial inflammation is an integral severity contributor to the progression of COVID-19 leading to a state of coagulopathy and thrombotic or hemorrhagic tendencies manifested as pulmonary embolisms, cardiovascular or CNS strokes particularly in patients with severe disease (87-90). In support of these observations, occlusive and non-occlusive acute coronary syndromes resulting in myocardial infarction have been observed in patients with minimal cardiac risk factors including considerably younger patients (79). These observations led to the importance of assessing the role of anticoagulation and antiplatelet therapy in COVID-19 where guidelines continue to evolve (91-94). Current guidelines do not support the routine prophylactic use of anti-coagulant/anti-platelet therapy in non-hospitalized patients unless clinical indications dictate otherwise. Furthermore, it has been recommended by different COVID-19 management guidelines that hospitalized non-pregnant adults with COVID-19 should receive prophylactic doses of anticoagulants such as low molecular weight heparin. What is the optimal anticoagulation approach in critically ill patients that require intensive support is unclear as three trials studying whether therapeutic doses reduce progression toward organ support have been halted since intervention therapy was observed to be ineffective for organ protection: (1) The Randomized, Embedded, Multi-factorial Adaptive Platform Trial for Community-Acquired Pneumonia (REMAP-CAP); (2) Therapeutic Anticoagulation; Accelerating COVID-19 Therapeutic Interventions and Vaccines-4 (ACTIV4); Antithrombotic Inpatient; (3) Antithrombotic Therapy to Ameliorate Complications of COVID-19 (ATTACC) (95).

One of the most intriguing phenomena of the clinical manifestations of the pandemic disease is the selective development of the immune mediated COVID-19 cytokine storm (CCS). The clinical condition develops toward the end of the first week following infection, probably the outcome of both specific pathogen and host related factors. Due to mechanisms, yet to be fully understood, a subgroup of patients instead of suppressing viral replications toward viral clearance and recovery, mounts an overwhelming catastrophic hyperimmune pro-inflammatory response characterized by the massive production of cytokines such as Tumor Necrosis Factor alpha (TNF-a), interleukins particularly IL1, 6, and 8. This hyper-immune pro-inflammatory response produces to ominous multisystem manifestations including prominent vascular 
permeability causing secondary cardiovascular instabilities, a hypercoagulable state leading to serious multitudes of venous and arterial thromboembolism, tissue inflammation and destruction culminating into ominous acute respiratory distress syndrome (ARDS) and frequently lethal consequences (96). The phenomena have been recognized early during the pandemic which instigated suppression of the harmful effects of the immune responses through various suppressive mechanism including steroids, anticoagulation, anti TNF treatment as well as interleukins monoclonal antibodies inhibitors including the IL-1 inhibitor, anakinra, and the IL-6 inhibitor, tocilizumab Eventually steroids proved to be beneficial as documented in the landmark RECOVERY trial which has been reciprocated (97). Despite conflicting efficacy results for tocilizumab from cohort and randomized clinical trials, evidence of significant benefits have been contradicted by data from larger randomized studies including met analysis suggesting that additional studies are required $(98-100)$.

\section{HOST RESPONSE TO COVID-19 INFECTION}

Understanding the host immune response to SARS-CoV2 infection is critical to understanding the pathogenesis of COVID-19, clinical manifestations, passive or active mediated responses such as monoclonal antibodies and convalescent plasma therapies, as well as vaccine development against the disease. The host immune response to COVID-19 determines susceptibility to the progression of infection as well as being a major determinant of recovery orchestrated by coordinated $\mathrm{B}$ and $\mathrm{T}$ cell responses (101). Furthermore, data concerning the durability of immunity to SARS-CoV-2 infection can assist in the continued development of successful vaccines and therapeutics for control of COVID-19.

Our current understanding of SARS-CoV-2 immunity is based mainly on previous experiences with other corona viruses including SARS-CoV and MERS-Co V viral infections, supplemented with studies of patients who were infected and recovered from SARS-CoV-2 infection $(102,103)$. Data on the biological (e.g., age, sex, and body mass index) and genetic factors responsible for disease severity to SARS-CoV-2 are just emerging. For example, neutralizing antibodies, and responses from $\mathrm{CD} 4^{+}$ and $\mathrm{CD}^{+} \mathrm{T}$ cells, might be associated with COVID-19 severity, with age being a risk factor (104). So far, current data indicate that innate immune and adaptive immune responses, including antibody production and T-cells, are involved in response to infection by SARS-CoV-2 and the pathogenesis of COVID-19.

\section{Innate Immune Response}

Based on previous knowledge of the innate immune response to other coronaviruses the conserved mechanisms of innate immune signaling can be seen in patients infected with SARSCoV-2 (105-107). Being an RNA virus, the SARS-CoV-2 innate immune response is triggered by pattern recognition receptors (PRRs) such as Toll-Like Receptors (TLRs) or Retinoic acidinducible gene I (RIG-I)-like from the components receptors
(RLRs) that enable to detect the virus (108). This elicits a downstream signaling cascade, which leads to secretion of cytokines such as type I/III interferons (IFNs), tumor necrosis factor alpha (TNF-a), interleukin-1 (IL-1), and IL-6 among other cytokines. These cytokines will induce antiviral activity in the host cells, which subsequently induces adaptive immune responses. Additionally, if released early as well as being properly localized, IFN-I can effectively control SARS$\mathrm{CoV}$ infection (109). Data from in vitro studies suggest that SARS-CoV-2 is susceptible to IFN-I/III pretreatment (110113). Other molecules of the innate immune system such as lymphocyte antigen six complex loci E (LY6E) and the IFNinduced transmembrane family (IFITM) proteins can inhibit SARS-CoV-2 (114-116).

However, this innate immune response is reported to be impaired during SARS-CoV and MERS-CoV infection by their non-structural proteins, which affects the overall cytokine production $(117,118)$. For example, SARS-CoV-1 inhibits IFNI both in vitro and in vivo (119-122). Studies have shown that SARS-CoV-2 lack strong type I/III IFN signatures, and patients with severe COVID-19 displayed impaired IFN-I signatures as compared to mild and moderate cases $(110,123)$.

\section{Humoral Immunity}

From previous experience of emerging infectious diseases, neutralizing antibodies have been identified as being pivotal immune components against viral infections. The major role of neutralizing antibodies is antigen binding and interaction with cells bearing $\mathrm{Fc} \gamma$-receptors to modulate subsequent targeted immune responses.

Similar to SARS-CoV infection (124), humoral immune response to SARS-CoV-2 infection is mediated by antibodies that are directed to viral surface glycoproteins, mainly the Spike (S) glycoprotein and the nucleocapsid protein $(125,126)$. These antibodies are detectable approximately 6 days after RTPCR confirmation of infection, and those directed against spike receptor-binding domain (RBD) demonstrate neutralizing ability and thus, viral clearance and prevention of infection (127). Following acute SARS-COV-2 infection, the time lag for the appearance of early IgM and late IgG antibodies ranges between 6 and 28 days being longer in milder cases $(101,128,129)$. IgG, $\operatorname{IgM}$, and IgA antibodies responses to the SARS-CoV-2 cysteinelike protease have also been reported in patients with COVID19, and these responses correlate with antibody titers to the nucleocapsid protein (130). It is likely that viral clearance and recovery require coordinated $\mathrm{B}$ and $\mathrm{T}$ cell function but what is not clear is if it provides long-lasting immunity and protection from reinfection, which is crucial when considering the variable immune responses, and the prospects of protective vaccination (101). In a cohort study of COVID-19, detectable antibodies were observed in $<40 \%$ patients within 1 week and increased within 2 weeks to $100,94.3$, and $79.8 \%$ for both or either, or IgM or IgG, respectively $(63,129)$. A longitudinal study looking at the kinetics of antibodies directed against the spike protein in patients with COVID-19 found that IgA antibodies were produced in the first week of the infection and peaks after 20-22 days, whereas IgM antibodies titers reached a peak level after 10-12 days and 
subsequently started to disappear 18 days after the onset of symptoms (131). Another study assessing the $\operatorname{IgG}$ responses to spike glycoprotein in COVID-19 patients found that IgG titers increased in the first 3 weeks after the onset of symptoms and started to decrease by 8 weeks (132).

Furthermore, data indicating that there is a rapid decrease, with 2-4 months, in the IgG antibodies responses directed against the viral RBD and nucleocapsid proteins in patients with mild COVID-19, suggesting that humoral immunity against SARSCoV2 infection might not be long-lasting in patients with mild disease $(133,134)$.

On the other hand, a prospective study of patients with severe COVID-19 disease, a prospective study found significantly higher $\operatorname{IgM}$ and $\operatorname{IgG}$ antibodies titers in patients with severe disease in comparison to those without (135). Two of the major concerns regarding the current pandemic are: a) the possibility of reinfection and b) the longevity of protective vaccinations. In the case of infection from SARS-CoV-1 virus, IgG antibodies were maintained for 2 and 3 years in 90 and $50 \%$ of the patients, respectively $(101,102)$. Similarly, in seasonal coronavirus $229 \mathrm{E}$ infections, nasal IgA were detected 1-year post-exposure, despite undetectable serum IgA antibodies $(101,136)$. Current evidence suggests that, IgM and IgG antibody levels against SARS-CoV-2, may be maintained for 7 weeks (137) with at least $80 \%$ reported in cases following 49 days post infection $(63,137)$. Of importance is a report that anti-spike or anti-nucleocapsid antibodies in response to Covid-19, last at least 6 months, and was associated with a reduced risk of SARS-CoV-2 reinfection in the ensuing 6 months (138). Additional longitudinal and large cohorts' studies of patients with COVID-19 are vital to understand mounted and fluctuations in immune dynamics over time as well as the duration of protection by functional neutralizing antibodies and potential for re-infection $(63,101,137,139)$.

Interestingly, host immune response provides a potential therapeutic option through harvesting recovered patients' convalescent plasma (CP). Despite encouraging anecdotal data from cohort studies of the beneficial role of $\mathrm{CP}$ in the management of COVID-19, this therapeutic approach is facing challenges including the availability of suitable donors to match the rising number of patients, inefficiency based on costeffectiveness as well as concerns of whether there is a lasting protective effect (140). As such, the current paucity of supportive evidence for CP make it less widely utilized (141). Distinctively, there may be differences amongst patients' subgroups and at what stage initiation of therapy is most beneficial as reflected in the positive data with CP from an RCT of 160 elderly patients with early symptomatic disease, suggesting that the benefits of CP in term of reducing disease progression are linked to waning of the immune response with age (142).

\section{Cell Mediated Immunity}

Recognition of SARS-CoV-2 antigens by pre-existing and crossreactive $\mathrm{T}$ cells generated during previous infection with human coronaviruses might contribute to the frequent presence of $\mathrm{T}$ cells reactive to SARS-CoV-2 in patients with COVID-19 (143). A strong T cell immune response has been demonstrated in convalescent people with asymptomatic or mild COVID19 (144).

A fundamental role of T-cell mediated immunity was shown through a response against SARS-Cov- 2 demonstrated by CD4+ $\mathrm{T}$ helper cells interacting with CD8 $+\mathrm{T}$ cells, along with natural killer cells, to drive the cytotoxic response to kill the infected cells (101, 145). Grifoni et al. (101) used HLA prediction algorithms and peptide mega-pools to identify SARS-CoV-2-specific T cells in 10 patients with COVID-19 and 11 healthy, unexposed control participants. Virus-specific $\mathrm{CD} 4^{+} \mathrm{T}$-cell responses were detected in seven (70\%) patients with COVID-19 and virus-specific $\mathrm{CD}^{+}{ }^{+}$T-cell responses were detected in all 10 patients with COVID-19, further indicating that most individuals can develop T-cell responses to SARS-CoV-2. The CD4+ T-cell response predominantly consisted of T-helper-1 (Th1) cells, characterized by high concentrations of IFN- $\gamma$ secretion directed against both structural (spike, nucleocapsid and membrane) proteins and non-structural proteins $(146,147) . \mathrm{CD}^{+} \mathrm{T}$-cell responses specific to SARS-CoV-2 produced IFN- $\gamma$ and tumor necrosis factor (TNF) $\alpha$, also reflective of Th1 response.

During the COVID-19 pandemic, one of the early features is the noticeable overall reduction in total lymphocyte count, particularly $\mathrm{CD} 4+$ and $\mathrm{CD} 8+\mathrm{T}$ cells, which correlates with disease severity as well as the development of critical complications $(101,148)$. Similarly, the role of type I interferons (type 1 INFs) in COVID-19 has been highlighted when observations showed that $10 \%$ of patients with life-threating pneumonia have neutralizing autoantibodies against type I IFNs suggesting a potential therapeutic role for IFNs (149). Furthermore, studies have shown that poor outcomes can be predicted in cases where there is a decrease in levels of CD8 $+\mathrm{T}$ cells and B cells or an increase in CD4+/CD8+ ratio $(101,145)$. It has been reported that the increase in $\mathrm{T}$-cell responses in SARS-Co-V-2 infections is correlated to the severity of the disease (101, 150).

Both $\mathrm{CD}^{+}{ }^{+} \mathrm{T}$-cell and $\mathrm{CD} 8^{+} \mathrm{T}$-cell responses occur in most patients infected by SARS-CoV-2 within the first 2 weeks after the onset of symptoms and produce mainly Th1 cells. The frequency of $\mathrm{CD} 4+\mathrm{T}$ cells targeted to the spike protein correlates with neutralizing antibody titers (101), which may suggest that the Tcell response might be different among COVID-19 patients with different disease severity $(144,151)$.

Overall, several studies of COVID-19 patients showed that both humoral and cellular immunity are involved in the pathogenesis of COVID-19. Better understanding of the host immune responses and the pathogen immune evasion strategies will help in the development of effective vaccines against COVID19 and hopefully a better future.

\section{COVID-19 IN CHILDREN}

Currently, the burden of COVID-19 in children has not been determined accurately because of the high prevalence of asymptomatic cases, and the lack of consensus on case definitions for screening, testing and disease severity in children (152). Additionally, febrile and respiratory illnesses are very common 
during early childhood, and, as a consequence, the diagnosis of COVID-19 may be easily overlooked (153).

The majority of published studies have concluded that children represent 1-2\% of diagnosed COVID-19 infections (154). The median age of the diagnosed children ranges from 3.3 to 11 years in different reports $(154,155)$. Typically following exposure to infected family members, children are predominantly asymptomatic or experience milder symptoms compared to adults (156-158). This low prevalence can be attributed to scarcity of clinical symptoms, higher testing thresholds, or lower reporting of cases (152).

In comparison to infected adults and older children, younger children with mild/moderate COVID-19 are likely to have higher nasal viral loads, giving way for a silent spread of the virus especially with sequential opening of schools, ultimately a potential indicator for second and third waves (159). In contrast, some studies negated the role of children in viral transmission to adults in a sharp contrast to the axiomatic concept of transmissions of other related respiratory viral infections (33, 157). The low spread of infections amongst children might be explained by the precautions taken by public health authorities such as closure of schools, and public facilities as well as the lockdown of entire communities. Since these measures are being gradually lifted, an increase in the number of infections might be expected, with a report from the United States revealing a $90 \%$ increase in COVID-19 infections among children (160).

A large-scale study of over 2,000 pediatric patients in China, revealed that $94.1 \%$ of children with confirmed/suspected COVID-19 were asymptomatic or showed mild to moderate symptoms, $4.4 \%$ of these were completely asymptomatic while approximately $6 \%$ became severely or critically ill (161). This may explain the observed low mortality of $<1 \%$ of all deaths (160). Nevertheless, it remains enigmatic if an immature immune response plays a protective role against the development of severe clinical manifestations in children $(71,162)$.

Regarding the clinical presentation of COVID-19 in children, respiratory symptoms are common, followed by fever and gastrointestinal symptoms $(156,157,163)$ while the rate of children with critical illness ranges from 0.4 to $9 \%$ of confirmed cases, probably reflecting population bias since some reports include mainly patients diagnosed at hospitals $(156,157,163)$. In various reports, almost $50 \%$ of the children admitted to the ICU had an underlying medical condition $(156,157,164)$.

A specific matter of concern is the comparatively high incidence of multisystem inflammatory syndrome (MIS) reported in children diagnosed with COVID-19 (165-168). MIS manifests with fever, elevated inflammatory markers and organ dysfunction not attributed to another infectious cause (168). The most common presentations of MIS in children are fever, headache, along with gastrointestinal, cardiovascular, and respiratory symptoms mucocutaneous involvement (skin rashes and non-purulent conjunctivitis) as well as limb edema (168-170). Raised inflammatory markers such as neutrophilia, elevated C-reactive protein and elevated ferritin are frequent, and, in addition, thrombocytopenia, lymphopenia, elevated troponin and elevated D-dimer and fibrinogen have been observed in children with MIS (171). MIS can take a severe course requiring ICU admission and mechanical ventilation (168-173). A large cohort study reported that $2 \%$ of MIS patients died and underlying medical conditions were reported in $50 \%$ of children who died with MIS $(169,170)$.

MIS in children might be a late complication of COVID19 because the median interval from the onset of COVID19 symptoms to the onset of MIS is 25 days, and the higher rate of positive serologic test compared to nasopharyngeal RT-PCR (167, 174). Several pathophysiological mechanisms have been suggested as underlying causes of MIS in children. Such mechanisms include formation of immune complexes, viral mimicry, and host immune cell activation due to viral superantigen sequences (175) Treatment in children infected with SARS-CoV-2 consists mainly of supportive care, including oxygen and advanced respiratory support, hydration, and antipyretics $(176,177)$.

In addition to supportive care, children diagnosed with MIS were treated with intravenous immune globulin, glucocorticoids, IL-1 and IL-6 receptor antagonists as well as TNF- $\alpha$ antagonists (173).

\section{COVID-19 IN ELDERLY POPULATION}

Elderly individuals infected with SARS-CoV-2 virus are at greater risk of developing severe infection and complications, leading to increased morbidity and mortality rates $(37,88,178)$. A large scale study involving 72,314 patients from China reported that case fatality was $8.0 \%$ in patients aged $70-79$ years and $14.8 \%$ in patients' aged $\geq 80$ years (179). Another study from Europe reported $48 \%$ mortality in patients' aged $\geq 85$ years (180). A demographic study measuring the contribution of age distribution of COVID-19 cases to the case fatality rates (CFRs) across nine countries, found that after age standardization, the highest CFRs were observed in Italy, Spain and the Netherlands, while the lowest CFR occurred in Switzerland, France, the USA and Germany (181). Sudharsanan et al., suggested that several factors such as the health of the population, the time of detection of COVID-19, the quality of care provided to patients and the state of preparedness within healthcare systems, could explain the differences in the CFRs across these countries (181).

Elderly patients usually have chronic medical illnesses and are likely to have severe or critically severe comorbidities. They might also show atypical symptoms without fever or cough and multiple organs dysfunction. Furthermore, most elderly patients at the emergency department present with atypical presenting illnesses including falls and may lack specific COVID-19 underlying symptoms $(182,183)$.

Several other studies have also suggested that elderly patients may not exhibit typical symptoms, such as fever or cough, when compared to young patients infected with SARS-CoV2 (184). Fever in the elderly patients might be masked and COVID-19 infections might only be manifested as cognitive or functional decline, especially in patients with pre-existing cognitive disorders (185). Additionally, elderly patients with COVID-19 may only have fatigue, myalgia, headache, or digestive symptoms, including anorexia, vomiting without fever, or cough 
$(37,182,183)$. Therefore, atypical presentations of SARS-CoV2 infection in elderly patients are frequent and may delay diagnosis of the disease. Clinical care providers for elderly patients should be aware of these non-classical presentations. Furthermore, elderly COVID-19 patients tend to have more inhospital complications when compared to younger populations (37). A multicenter retrospective study carried out in Hunan Province in China found that about $40 \%$ of elderly patients had complications such as acute respiratory distress syndrome, acute cardiac injury, acute kidney injury, sepsis and pneumothorax in comparison to $14.1 \%$ in younger patients (182). Moreover, more elderly patients received invasive mechanical ventilation compared to younger patients (182).

The underlying pathophysiology that leads to the worst outcomes in the elderly is poorly understood but probable contributing factors are waning immunosenescence and agingrelated low-level proinflammatory responses leading to a gradual decline in the immune response creating a susceptible host.

Several mechanisms have been postulated to contribute to the observed higher risk of severe COVID-19 in the elderly (186), including: (a) increase in co-morbidities especially hypertension, diabetes, obesity and respiratory diseases; (b) the atypical presentation of illness or lack of any specific symptoms of the underlying COVID-19 in the elderly may delay the diagnosis and early management of these patients; (c) with aging, there is a decrease in the innate immune response, and a shift in $\mathrm{T}$ cell subpopulations leading to a decrease in naïve T-cells and an increase in memory T-cells, which limits the response against novel infectious agents (186-190); and (d) in the elderly public health measures and quarantining of infected individuals might not be an easy task, especially with cognitively impaired patients (191, 192).

\section{COVID-19 THERAPEUTICS}

In the absence of effective drugs with established therapeutic efficacy against SARS-CoV-2, considerable attention has been focused on re-purposing currently available drugs for the treatment of COVID-19 (193). Drug trials have included antiviral agents that were primarily licensed or developed for the treatment of influenza (oseltamivir, favipavir, umifenovir), HIV (lopinavir, ritonavir, azvudine), hepatitis (ribavirin, sofosbuvir), Ebola (remdesivir), herpetic infections (penciclovir), antibiotics with antiviral or anti-inflammatory properties (azithromycin), anti-parasitic including anti-malarial drugs (chloroquine, hydroxychloroquine, ivermectin), and the histamine-2 antagonist with anti-viral activities (famotidine). To circumvent or augment immune responses, several immunomodulatory drugs have also been studied including steroids, interferons, colchicine, interleukin inhibitors (tocilizumab, anakinra) as well as convalescent plasma. Therapies specifically directed at SARS-CoV-2 include the use of recombinant human ACE2 proteins to act as decoy receptors for the SARS-CoV-2 virus. An indication of the global research effort is reflected by a report stating that there are over 2,000 clinical trials assessing over 700 potential COVID-19 therapies (194). However, a "living" systematic review in the British Medical Journal concluded that: "the effectiveness of most interventions is uncertain because most of the randomized controlled studies so far have been small and have important study limitations" (195) This conclusion has been reemphasized by Tikkinen et al. (196) stating: "several false claims of efficacy have emerged from non-randomized comparisons-." In contrast, reports from the RECOVERY (Randomized Evaluation of Covid-19 Therapy trial) Collaborative group in the U.K. have established the benefits of a 28-days treatment with the steroid dexamethasone in reducing mortality and progression to ventilation support in patients with COVID-19; in contrast, no benefits were associated with the combination of lopinavir plus ritonavir (197).

\section{Chloroquine and Hydroxychloroquine}

The initial interest in chloroquine and hydroxychloroquine was understandable as following the SARS epidemic in 2002, data from in vitro studies suggested that the drugs possessed both anti-viral and anti-inflammatory properties linked to their ability to raise endosomal $\mathrm{pH}$ in the host cell and inhibit glycosylation of the host ACE2 (Figure 3A) (198); a conclusion supported by data from China (88), but later challenged by data from in vivo studies with macaque monkeys (199). In vitro studies also suggest that chloroquine and hydroxychloroquine could block the binding of the virus to ACE2; however, the concentrations required would most likely be toxic if used clinically and would raise the risk of cardiac dysrhythmias (200). Furthermore, hydroxychloroquine and chloroquine have been extensively used for treating malaria, lupus erythematosus and rheumatoid arthritis and since their pharmacokinetic and toxicity profiles were well-known their use was considered safe. Unfortunately, inadequacies in the design of some of the clinical trials investigating these drugs in COVID-19 have resulted in contradictory results. In March 2020 clinical support for the effectiveness of a combination of hydroxychloroquine with the macrolide antibiotic, azithromycin, in reducing the viral load of SAR-CoV-2 in patients was acclaimed and widely publicized following an open label non-RCT study from Marseille (201). However, the small number of patients with a questionable recruitment process together with non-congruent results raised questions as to interpretation of the data. Nevertheless, in the absence of alternative options many global healthcare authorities endorsed use of hydroxychloroquine, including the FDA with the latter approving Early Use Authorization for hydroxychloroquine on March 28th 2020 (202). Subsequently, randomized control trials from Canada and the USA failed to demonstrate a post-exposure prophylaxis benefit (203). Similarly, a multicenter, open label randomized controlled study in Brazil using hydroxychloroquine and azithromycin not only failed to demonstrate beneficial outcomes but also reported adverse events including cardiac and hepatic toxicities (204). To complicate the scientific debate, retrospective studies produced conflicting results with one reporting no benefits of hydroxychloroquine or azithromycin alone, or in combination, to reduce inhospital mortality (205), and another reporting a reduction in mortality with hydroxychloroquine alone or in combination with azithromycin versus standard of care (SOC) (206). In 
the latter study a far greater number of patients treated with hydroxychloroquine and/or azithromycin also received steroids, a confounding Achilles heel weakness apparent in retrospective studies (37). In late April 2020, the FDA reversed its approval and cautiously advised against the use of hydroxychloroquine or chloroquine outside clinical trial or hospital settings. Finally, data from the RECOVERY trial which is by far the largest RCT to date, annulled the effectiveness of hydroxychloroquine concluding: "In patients hospitalized with COVID-19, hydroxychloroquine was not associated with reductions in 28-days mortality but was associated with an increased length of hospital stay and increased risk of progressing to invasive mechanical ventilation or death" (207). Despite the evidence against the use of chloroquine or hydroxychloroquine the controversy continues. A meta-analysis that was posted on September 30th 2020 on the medRxiv preprint server concluded that hydroxychloroquine use in outpatients reduced hospital stay and mortality despite none of the five RCTs included in the analysis individually demonstrating benefit (208).

\section{Remdesivir}

The anti-viral drug, remdesivir was originally developed for hepatitis $\mathrm{C}$ and later tested for Ebola and the pharmacokinetic and toxicity profile for this drug are also established albeit limited to data from small RCTs. Remdesivir is a pro-drug that readily enters cells where it undergoes hydrolysis to an active form by esterase enzymes to a triphosphorylated adenosine analog that competitively inhibits RNA-dependent polymerase resulting in termination of replication chain (Figure 3A). In vitro results indicate that the anti-viral activity of remdesivir is effective at sub, or low micromolar concentrations against other coronaviruses including MERS-CoV and subsequently supported by an in vivo study in Rhesus monkeys $(209,210)$. A multi-center RCT from China (211) compared the clinical outcomes of 158 with severe COVID-19 treated for 28 days with remdesivir against 78 patients provided with SOC. The authors concluded: "In this study of adult patients admitted to hospital for severe COVID-19, remdesivir was not associated with statistically significant clinical benefits." The study also failed to demonstrate that remdesivir reduced the viral load. The results from an international multi-center study (ACTT-1) of hospitalized COVID-19 patients demonstrated that remdesivir in comparison to placebo shortened the time for recovery by 5 days, but did not reduce mortality, in adults hospitalized with COVID19 and evidence of lower respiratory infection (212). Conversely, a study comparing 5 vs. a 10-days remdesivir treatment, but lacking a matching comparator SOC arm, found no difference in outcomes (213). Results, from a third RCT demonstrated a modest benefit for a 5-days management course but intriguingly not for a 10-days course (214). Finally, the interim results from the WHO SOLIDARITY multi-center international RCT indicate no benefits of remdesivir, hydroxychloroquine, lopinavir or interferon on overall mortality or initiation of ventilation and duration of hospital stay (215). Critically, RNA viral load was not measured to reflect anti-viral efficacy. In conclusion, the results from the clinical trials with remdesivir do not show that it reduces viral load or mortality rates although there is evidence from some but not all studies that patients recovered more rapidly.

\section{Dexamethasone}

Although glucocorticoids, such as dexamethasone, will suppress the host's immune response and increase the risk of enhancing viral replication and potentially activate a latent infection such as tuberculosis or hepatitis they can be beneficial to counteract a hyperinflammatory cytokine storm as seen in severely ill COVID19 patients (Figure 3B). The results of a RCT from the UK based RECOVERY study group demonstrated significant efficacy for the use of dexamethasone (207).

\section{Ivermectin, 3CLpro and PLpro Inhibitors}

Another promising drug target is cysteine protease, Mpro (or 3CLpro), a precursor polyprotein, which is essential for viral cleavage (216). There is considerable interest in the potential antiviral benefits of the widely used broad-spectrum antiparasitic drug ivermectin as a putative inhibitor the importin $\alpha / \beta 1$ protein complex preventing nuclear import and also inhibit the 3CLpro protease thus preventing viral replication (217219). There is an extensive literature that supports the safety of ivermectin to treat a variety of parasitic infections as well as in vitro and in vivo data reflecting anti-SARS-CoV-2 effects (220). Although not receiving FDA approval for COVID-19 disease, ivermectin has been used for the treatment of the disease in a number of countries and notably in Peru where its use has been linked to a decrease in both mortality and lethality although in the absence of data from appropriate RCTs other non-drug related factors may have contributed to the apparent benefits of treatment $(221,222)$. An exploratory Phase 1 clinical trial has been approved in the U.K. by the Medicines \& Healthcare products Regulatory Agency) to determine the therapeutic efficacy of ivermectin as a low cost prophylactic to prevent the spread of COVID-19 (223). Several other 3CLpro inhibitors are also being investigated including GC376, and its analog GC373, which are currently used to treat the fatal feline infectious peritonitis caused by a coronavirus. Both GC376 and GC373 have been shown to be very potent inhibitors of SARS$\mathrm{CoV}-2$ in a cell culture protocol using monkey and human lung cells infected with SARS-CoV-2. The drugs were effective with $\mathrm{IC}_{50}$ values in the nano-molar range with no apparent toxicity (224). Another target is the papain-like protease, PLpro, which plays an important role in dampening the host's inflammation and antiviral signaling pathways including inhibition of type I interferon production (225).

\section{Famotidine}

Famotidine is a histamine receptor 2 (H2) antagonist that is widely used as an antacid and in vitro studies indicate that the drug has inhibitory effects on several viral proteases including 3CLpro, PLpro and TMPRSS2 (226). Retrospective clinical data are supportive of the benefits of famotidine in reducing mortality in COVID-19 patients independent of its gastric acid lowering action as indicated by the lack of benefits associated with the use of proton pump inhibitors (227). Data from a number of Phase III clinical trials with famotidine are expected in 2021. 


\section{TMPRSS2 and Furin Inhibitors}

In addition, there are several experimental drugs, which appear promising as potential serine protease inhibitors that target the two host enzymes, TMPRSS2 and furin that are hijacked by the SARS-CoV-2 virus, to facilitate binding to ACE2 and entering the host cell (228-230). Camostat mesilate, a drug approved in Japan for use in pancreatic inflammation, and the related nafamostat, have also been shown in in vitro studies to inhibit TMPRSS2, with IC50s of 142 and $55 \mathrm{nM}$, respectively (231). Camostat is undergoing clinical trials for the treatment of COVID-19 with one with the Identifier NCT04608266 now in Phase III "A Multicenter Randomized Trial to Evaluate the Efficacy and Safety of Camostat Mesylate for the Treatment of SARS-CoV-2 Infection-COVID-19 in Ambulatory Adult Patients (CAMOVID)." Worthy of note is that because TMPRSS2 and furin are important for a variety of cellular processes in the host the risk of side effects may be heightened with the chronic use of inhibitors of these enzymes.

\section{Convalescent Plasma and Targeted Antibody Therapy}

As previously mentioned the clinical data supporting the use of convalescent plasma therapy for treating COVID-19 patients has not demonstrated positive benefits (141); however, progress has been made in the use of synthetic antibodies to treat COVID19 patients. Eli-Lilly received EUA from the FDA for their single antibody, bamlanivimab (LY-CoV555) on the 9th November 2020 and on the 21st November the biotechnology company Regeneron also received EUA for their product, REGN-CoV2. LY-CoV555 is a single highly potent antibody isolated from convalescent COVID-19 patients that binds to the RBD of the virus spike protein (232). Regeneron's antibody cocktail consists of two antibodies, casirivmab (REGN10933) and imdevimab (REGN10987) that also target and irreversibly bind to the RBD site on the SARS-CoV-2 spike protein and was also based on screening human neutralizing antibodies from recovered COVID-19 patients (233). For both LY-CoV555 and REGNCoV2 positive data has been published indicating that the antibody cocktails are particularly effective in patients with high viral loads or whose immune system had not responded to the virus, however, they are not effective in severely ill hospitalized patients $(103,234,235)$. AstraZeneca is also developing an antibody targeted therapy, AZD7442, for the prophylactic treatment of adults exposed to COVID-19 with data from a Phase III clinical trial, NCT04507256, expected in 2021 (236).

\section{VACCINE PROGRESS}

When compared with other epidemic viruses, SARS-CoV-2 is unique as it is highly contagious, can be transmitted easily even before development of clinical symptoms and has been associated with significant morbidity and mortality. Although the virus has spread to all continents, the total number of those infected $(\sim 2 \%)$ is well below estimated need for herd immunity $(\sim>70 \%)$ hence there is urgency for the development of effective vaccines. The benefits of effective vaccines are well-established as has been well-documented for other historic pandemics (237). The global acceptance of effective vaccines will allow for relaxing restrictive measures and recovery of socioeconomic conditions as well as reversal of the psychological consequences associated with a pandemic. There has been a global response to developing vaccines and its acceptance, and an up to date status can be found through accessing vaccine tracker sites (238).

In April 2020 the US government launched Operation Warp Speed (OWS) with the objective of delivering at least 300 million doses of a safe and effective vaccine by January 2021 (239). The process involves collaboration between several government agencies including the Department of Health and Human Services (HHS), the Centers for Disease Control and Prevention (CDC), the Food and Drug Administration (FDA), the National Institutes of Health (NIH), and the Biomedical Advanced Research and Development Authority (BARDA), as well as the Department of Defense (DoD). However, there are concerns regarding OWS and its potential to damage international efforts to make effective vaccines globally available and this is evident by the exclusion of cooperation with the WHO, the European Commission, and the Coalition for Epidemic Preparedness Innovations (CEPI) as well as exclusion of vaccines from China. CEPI, based in Norway, was launched in 2017 with co-funding by the Bill and Melinda Gates Foundation, the Welcome Trust and a consortium of nations and is recognized as a key player in the development of vaccines against potential epidemic threats (240).

\section{Leading Potential Vaccines}

A comparison of the leading potential and approved vaccine platforms for SARS-CoV-2 can be found at $(241,242)$ and are summarized in Table $\mathbf{1}$.

\section{Viral Vectors Vaccines}

The concept of viral vector vaccines is based upon deployment of viral particles such as the SARS-CoV-2 S spike attachment proteins and other similar proteins through a suitable replication deficient vector such as human or Chimpanzee adeno or influenza viruses to produce an appropriate immune response. The approach has been researched for several years and has demonstrated preliminary success against Dengue virus, Ebola virus disease, Zika virus and candidate vaccines for MERS$\mathrm{CoV}$ (254). However, pre-existing immunity from previous related viral infections has shown to diminish appropriate responses (255).

Four vector vaccines are at different advanced level of efficacy evaluation or granted emergency approval by licensing authorities at different countries:

1. CanSino Biologics (Ad5-nCoV) from China, which utilizes replication deficient human adeno virus-5 as a vector in a single dose (248). Ad5-nCoV has demonstrated immunogenic responses in Phase I/II trials with good safety profiles and has been released for Phase III trials in China, the Middle East and South America. In August 2020 Chinese authorities granted accelerated vaccine patency and approval.

2. Gamaleya (Sputnik V vaccine) from Russia, which uniquely deploys dual replication deficient recombinant human 
TABLE 1 | Details of prime potential or approved COVID-19 vaccines and their latest stages of development.

\begin{tabular}{|c|c|c|c|c|c|c|}
\hline Vaccine platform & $\begin{array}{l}\text { Candidate } \\
\text { vaccine }\end{array}$ & Mechanism & Research institute & $\begin{array}{l}\text { Planned route; } \\
\text { doses }\end{array}$ & $\begin{array}{l}\text { Published phase } 1 \& 2 \\
\text { results }\end{array}$ & $\begin{array}{l}\text { Status of phase } \\
3 \text { clinical trials }\end{array}$ \\
\hline $\begin{array}{l}\text { Recombinant protein } \\
\text { particles vaccines }\end{array}$ & NVX-CoV2373 & $\begin{array}{l}\text { Deployment of full length } \\
\text { recombinant viral spike } \\
\text { protein with Matrix M } \\
\text { adjuvant }\end{array}$ & Novavax, USA & $\begin{array}{l}\text { IM; Two: day } 0 \text { and } \\
\text { day } 21\end{array}$ & $(243)$ & $\begin{array}{l}\text { Completed } \\
\text { enrollment, results } \\
\text { expected March } \\
2021\end{array}$ \\
\hline Inactivated & $\begin{array}{l}\text { Three inactivated } \\
\text { vaccines }\end{array}$ & $\begin{array}{l}\text { Whole virus propagated } \\
\text { into cell culture line then } \\
\text { inactivated with organic } \\
\text { compounds. Purified } \\
\text { material adsorbed with } \\
\text { aluminum adjuvant }\end{array}$ & $\begin{array}{l}\text { Sinopharm, } \\
\text { Wuhan/Beijing Institute } \\
\text { of Biological Products, } \\
\text { China }\end{array}$ & $\begin{array}{l}\text { IM; Three: day } 0 \text {, day } \\
28 \text {, and day } 56\end{array}$ & $(244)$ & $\begin{array}{l}\text { Started Jul 2020, } \\
\text { No published } \\
\text { results } \\
\text { Approved for } \\
\text { emergency use }\end{array}$ \\
\hline \multirow[t]{3}{*}{ Vector based } & $\begin{array}{l}\text { ChAdOx1- } \\
\text { S/AZD1222 }\end{array}$ & $\begin{array}{l}\text { Deployment of spike } \\
\text { protein through replication } \\
\text { deficient Chimpanzee } \\
\text { adeno virus }\end{array}$ & $\begin{array}{l}\text { University of } \\
\text { Oxford/Astra Zeneca, } \\
\text { UK }\end{array}$ & IM; Two day 0 and 28 & $(245-247)$ & $\begin{array}{l}\text { Published Dec } \\
2020 \\
\text { Approved for } \\
\text { emergency use }\end{array}$ \\
\hline & $\begin{array}{l}\text { Ad5-vectored } \\
\text { COVID-19 }\end{array}$ & $\begin{array}{l}\text { Deployment of spike } \\
\text { protein through replication } \\
\text { deficient type five adeno } \\
\text { virus }\end{array}$ & $\begin{array}{l}\text { CanSino Biological } \\
\text { Institute/Beijing Institute } \\
\text { of Biotechnology, China }\end{array}$ & IM; Single & $(248)$ & $\begin{array}{l}\text { Started June } 2020 \\
\text { No published } \\
\text { results } \\
\text { Approved for } \\
\text { emergency use }\end{array}$ \\
\hline & $\begin{array}{l}\text { Gam-COVID-Vac } \\
\text { (Sputnik V) }\end{array}$ & $\begin{array}{l}\text { Deployment of spike } \\
\text { protein through replication } \\
\text { deficient type } 5 \text { and } 26 \\
\text { adeno viruses }\end{array}$ & $\begin{array}{l}\text { Gamaleya Research } \\
\text { Institute, Russia }\end{array}$ & $\begin{array}{l}\text { IM; Two: day } 0 \text { and } \\
\text { day } 21\end{array}$ & $(249)$ & $\begin{array}{l}\text { Started Sep } 2020 \\
\text { No published } \\
\text { results } \\
\text { Approved for } \\
\text { emergency use }\end{array}$ \\
\hline \multirow[t]{2}{*}{ mRNA } & mRNA-127 & $\begin{array}{l}\text { Nanoparticle formulated } \\
\text { mRNA encoding spike } \\
\text { protein or receptors } \\
\text { binging proteins }\end{array}$ & Moderna, USA & $\begin{array}{l}\text { IM; Two: day } 0 \text { and } \\
28\end{array}$ & $(250,251)$ & $\begin{array}{l}\text { Published Dec } \\
2020 \\
\text { Approved for } \\
\text { emergency use }\end{array}$ \\
\hline & BNT162b1 & & $\begin{array}{l}\text { BioNTech/Fosun/Pfizer, } \\
\text { Germany, USA }\end{array}$ & $\begin{array}{l}\text { IM; Two: day } 0 \text { and } \\
\text { day } 21\end{array}$ & $(252,253)$ & $\begin{array}{l}\text { Published Dec } \\
2020 \\
\text { Approved for } \\
\text { emergency use }\end{array}$ \\
\hline
\end{tabular}

IM, Intramuscular.

adenoviruses (Ad5 and Ad26) for immune evasion that requires two doses. The Sputnik V vaccine has been granted early approval after the published results indicate combined vaccine immunogenicity profiles particularly following the second dose, as well as a positive safety profile $(249,256)$.

3. University of Oxford/AstraZeneca (ChAdOx1 nCoV-19) vaccine, which utilizes replication deficient Chimpanzee adenovirus for immune evasion. ChAdOx1 nCoV-19 has received considerable interest from many healthcare authorities since it was believed to be ahead of other vaccines based upon earlier progress as a candidate for the related MERS-CoV (245). In May 2020, ChAdOx1 nCoV-19 vaccine became the first vaccine to be tried against COVID-19 in humans and has demonstrated favorable immunogenic and safety profiles in Phase I/II trials. ChAdOx1 nCoV-19 entered Phase III trials in July 2020, and Phase II/III data published from randomized controlled studies in Brazil, South Africa and UK published in December 2020 (238). Due to a dosing error in the UK study some vaccine vials were filled with half the intended dose and the protocol was changed so as to compare people who received a half dose followed by the full dose with those given two full doses. The results were interesting as the effectiveness was higher, $90 \%$, for those who first received a half dose vs. who received the full dose for both injections, $62 \%$, which intriguingly raises the possibility that the full first dose vector mediated immunogenicity, which might hampered efficacy of the second dose. The observation certainly caught the attention of the trial investigators and it will be pursued with additional studies.

On December 30th 2020, ChAdOx1nCoV-19 was approved for use in the UK for use in 18 years or older An advantage of the Oxford/AstraZeneca vaccine vs. the mRNA vaccines is its stability at regular refrigerator temperature and relatively low cost agreed with manufacturer at $\$ 2$ to $\$ 3$ USD/dose $(257,258)$.

In December 2020, AstraZeneca announced collaboration with Gamaleya to determine if the appropriate combination of ChAdOx1nCoV-19 with the Sputnik V vaccine will further boost effectiveness (259). 
Ad26.CoV2-S produced by Johnson and Johnson Pharmaceuticals is a non-replicating adenovirus serotype 26 vector- based vaccine expressing the stabilized pre-fusion spike (S) protein of SARS-CoV-2, initially planned as a single dose formulation, but now with a trial as a two-dose formulation (238). Data from a Phase $1 / 2$ clinical study demonstrated that the safety profile and immunogenicity after a single vaccination were very encouraging which allowed the investigators to move to a Phase 3 clinical trial (238).

\section{Inactivated Virus Vaccines}

Based on a well-established vaccine methodology, inactivated virus technique is simple and attractive. In China Sinovac/Instituto Butantan have reported success of PhaseI/II trials and their vaccine, CoronVac, entered Phase III studies in Brazil, Indonesia, and Turkey using an inactivated vaccine cultured in Vero cell line, inactivated with inorganic compounds then combined with an aluminum adjunct (244, 260). A limitation is that there are, to date, no phase III data published in peer-reviewed journals. However, media reports from Turkey stated the vaccine's seroconversion is as high as $97 \%$, though this does not refer to its effectiveness, and preliminary data from a trial in Brazil stated, according to a media release on January 8 th, 2021, effectiveness of $78 \%$, but subsequently revised to $50.4 \%$ (261).

Similarly, the Beijing Institute of Biological Products developed BBIBP-CorV, which is also based on an inactivated virus platform as for CoronaVac. This vaccine has undergone clinical trials through the state-owned SinoPharm and received emergency use in China in mid-2020 and administered to $>20$ million Chinese. In addition, as a result of Phase III trial data effectiveness is reported to be between 79 and $86 \%$ and in September 2020 the vaccine was provided to health care workers in UEA and became fully available to the public in early December 2020 (262).

\section{Recombinant Technology}

In the USA Novavax (NVX-CoV2373) has developed a nanoparticle vaccine based on the SARS-CoV-2 spike glycoprotein recombinant technology with Matrix-M1 immunogenic adjuvant and favorable efficacy and safety profiles have been published (243). Integral to the vaccine's technology are the advantages of the capability for mass production, relatively cheap costs, together with ease of storage; all crucial requirements for ideal vaccine development. A randomized clinical trial to assess efficacy has been completed in the UK with enrollment of 15,000 patients and plans to publish the results in the first quarter of 2021. Additional clinical trials are also underway in Mexico and South Africa (263).

\section{mRNA Vaccines}

In recent years, the use of nucleic acid-based technology for vaccine production has developed rapidly and has overcome previous delivery problems by utilizing encapsulated lipids nanoparticles $(264,265)$. Once the gene sequence is known a nucleic acid-based vaccine can be developed rapidly and subject to the success of clinical tests could be available for use within a year; a potential issue is the need for low temperature storage, which for BioNTech/Fosun/Pfizer (BNT162) is -70C. In the case of COVID-19 an mRNA vaccine would provide the genetic information, and not directly the protein, to produce the spike protein to which the host now makes protective antibodies.

Progress with the mRNA 1273 mRNA-based vaccine was rapid, and it demonstrated favorable immune responses both in younger and older patients without significant adverse events (250, 266, 267). Similarly, BNT 162 completed Phase1 studies and entered a Phase II/III safety and efficacy evaluation with preliminary data released on November 9th 2020. Phase III data published in late 2020 indicate that both the Moderna/NIAID (mRNA1273) and BioNTech/Fosum/Pfizer (BNT162) vaccines demonstrate $>90 \%$ efficacy at preventing COVID-19 and with only transient local and systemic adverse reactions (251-253, $268,269)$. Both vaccines have received EUA in several countries and the first person to be vaccinated with the mRNA vaccine, BNT162, was a 90-years old woman in the United Kingdom on December 8th, 2020). The mRNA vaccines may prove to be more expensive than others because of the cost of the advanced technology and for Moderrna's vaccine, which has already been priced at \$74.00 USD for a full two-dose course (270). Although not evident from the Phase III studies several severe allergic responses have been reported for the BNT162 vaccine in people who had a previous history of allergies and may be attributed to the use of polyethylene glycol in the packaging of the lipid nanoparticles (271).

\section{Other Potential Vaccines}

Included in the international efforts to develop a vaccine for COVID-19 is a team at Imperial College, London, who are developing a self-amplifying RNA vaccine that theoretically should provide greater efficacy than other mRNA vaccines and is in Phase I/II studies (272).

\section{COMPARISON OF HOW COUNTRIES HAVE RESPONDED TO COVID-19 AND PREPARING FOR FUTURE PANDEMICS}

In the absence of an effective vaccine or drugs with proven effectiveness against SARS-CoV-2 other NPIs, including quarantine, track and trace technologies, and mandatory mask wearing, have been variably used by countries with vastly different effectiveness. We briefly review these issues and discuss how the lessons learnt can help prepare the world for future pandemics.

The level of preparedness of countries to deal with a major health emergency such as a pandemic was reviewed in 2019 in the Global Health Security (GHS) report (ghsindex.org). The GHS ranked 195 countries in six categories: Prevention; Detection and Reporting; Rapid Response; Health System; Compliance with International Norms; and Risk Environment. The USA and the UK were ranked $\# 1$ and $\# 2$, respectively for demonstrating highest level of preparedness. In terms of Asian countries only Thailand (\#6), South Korea (\#9), and Malaysia (\#18) appeared in the top 20 with Vietnam ranked \#50, and China \#51; Taiwan 
was not included. When these rankings are compared to the numbers of COVID-19 infections and deaths per their respective population size it is clear that the GHS rankings do not correlate well with the response to COVID-19 (1). Thailand, South Korea and Malaysia initially managed to keep the rate of infections and deaths relatively low compared to the other aforementioned countries and Vietnam fared even better and their successful strategy can be credited to its experience in 2003 with SARS$\mathrm{CoV}$ and best summarized as "Survival of the Smartest" (273). After the first COVID-19 patient was confirmed on January 21st 2020 the Taiwan CDC launched a proactive campaign to investigate and track and trace contacts and as of November 3rd has kept deaths $<10$ per million population (274). Eliminating or maintaining a low level of infections has proved difficult for some countries and a retrospective analysis of how different countries have fared will be valuable for planning for future pandemics. Of particular importance, as discussed by Haug et al. (275), will be determining which NPIs are effective and at the same time minimize negative impacts on the health of the public and economy. Thus, whereas lockdowns, curfews, restrictions on travel and gatherings including school closures, imposing work from home policies are among the most effective measures there are also negative consequences such as negative effects on the education and social development of children, domestic violence as well-neglecting the follow up of patients with chronic diseases such as cancer and major effects on the economy (275). Evidence of the value of lockdowns to contain the spread of the virus was provided by New York State, which was initially hit very hard by COVID-19 pandemic, but the subsequent lockdown resulted in an estimated $>50 \%$ reduction in transmission for all age groups and an $\sim 7 \%$ overall reduction when the wearing of a facemask was required (276).

The "Independent Panel for Pandemic Preparedness and Response," consisting of 13 health experts and former political leaders has been established by the WHO to review the response to COVID-19 in its member countries; the report will strive to provide useful insights and aid in planning for future pandemics. Meanwhile, post-hoc analysis has started with a report in The Lancet on September 24th that compared how five countries in Asia (Hong Kong, Japan, New Zealand, Singapore and South Korea) vs. 4 in Europe (Germany, Norway, Spain and UK) responded to the challenges of easing COVID-19 restrictions through until mid-June 2020 (277). The report analyzed six approaches: Overall Strategy; Knowledge of infection status; Community Engagement; Public-Health Capacity; Health-System Capacity, and finally, Measure for Border Control. One of the universally identified bottlenecks in mounting a rapid response was the frailty of the medical supply chain.

Amongst the confusing messages that may have perpetuated the spread COVID-19 was the question of the benefits of the use of facemasks and the importance of aerosol spread; the latter being particularly important in enclosed areas with inadequate ventilation. Some countries recognized the benefits and made the use of facemasks mandatory whereas others dithered and in consequence public acceptance was compromised (278). Unfortunately, there are only a limited number of studies that have rigorously investigated the effectiveness of different types of masks (279). Of interest, but requiring further study is evidence presented in The New England Journal of Medicine, albeit speculative, suggests that wearing a mask may help develop immunity via variolation $(280,281)$.

One year after SARS-CoV-2 was first identified, questions still remain concerning the pathophysiology of COVID-19. Especially problematic is the persistence of symptoms in patients in the absence of a positive COVID-19 test; the so-called "lasting misery of coronavirus long haulers" with an estimate that $10 \%$ of those infected with SARS-Co-2, may be facing long-term pulmonary and cardiovascular and other disabilities (281). In addition, the identification of cases of reinfection raises the question of how long immunity will last (282). On the other hand, we have gained considerable knowledge about optimizing supportive care for COVID-19 patients including the use of prone positioning for those with moderate to severe respiratory distress (283).

Many European countries, United States, Canada, India, South Africa and Brazil saw a resurgence in cases during the autumn/winter of 2020, and health authorities in these countries brought back lockdowns and other restrictions to curb infections. Several reasons can be offered to explain the spike in COVID19 cases in these countries, among these are (a) countries in the Northern hemisphere did not see a summer increase in COVID-19 cases, but when the temperature started to cool in the autumn and winter people spent more time indoors, less social distancing and increasing the risk of viral transmission; (b) Covid-fatigue caused people to lapse in their use of NPIs and lack of vigilance at home and away; (c) the re-opening of schools also may have contributed to the increase in transmission and spread by asymptomatic children (284); and (d) increases in the transmission rate, which has been attributed to the emergence of new SARS-CoV-2 variants such as B.1.1.7 in the United Kingdom and 501.v2 in South Africa $(68,285)$.

The WHO has warned that the virus will continue to spread rapidly in 2021 (34). Several countries have approved coronavirus vaccines for use but as populations await their rollout, cases remain high across many parts of the world (286).

\section{CONCLUSION}

Global collaborative efforts are required for better control of the current pandemic and to plan for future pandemics. A team at University College London has developed a computer-modeling program that uses data about societal impact on the environment, including climate and changes in animal habitat, to predict where future zoonotic pandemics might emerge (287). This approach successfully predicted the origins, but not the specific timing, of the Ebola outbreak (288). "Global Virome" has a scientific board comprised of leaders in the fields of global health and pandemic prevention with the goal of global collaboration via the "Trinity Challenge" initiative (289). Morens and Fauci (290) remind us that pandemics are not new and they discuss the impact of re-emerging/resurging pandemics such as tuberculosis, SARSCoV, MERS-CoV, and SARS-CoV-2. Vidal (287) and Morens 
and Fauci (290) emphasize the negative effects that humans have on the environment and inevitably we must expect "backlashes" from nature.

\section{AUTHOR CONTRIBUTIONS}

AS wrote the manuscript with substantial input from all the authors $\mathrm{HD}, \mathrm{CT}$, and $\mathrm{HH}$ therapeutics and vaccines. $\mathrm{HH}$ pathophysiology. MI figure. CT, DB, HD, EF, HH, MI, and AS

\section{REFERENCES}

1. Johns Hopkins University and Medicine. Coronavirus Research Center. (2020) Available online at: https://coronavirus.jhu.edu/map.html (accessed November 12, 2020).

2. Nebehay S. One in 7 Reported COVID-19 Infections is Among Health Workers, WHO Says. Reuters: Geneva (2020). Available online at: https:// www.reuters.com/article/us-health-coronavirus-who-healthworkersidUSKBN2681TR (accessed September 15, 2020).

3. Wang C, Horby PW, Hayden FG, Gao GF. A novel coronavirus outbreak of global health concern. Lancet. (2020) 395:4703. doi: 10.1016/S0140-6736(20)30185-9

4. Shi Y, Wang G, Cai XP, Deng JW, Zheng L, Zhu HH, et al. An overview of COVID-19. J Zhejiang Univ Sci B. (2020) 21:34360. doi: 10.1631/jzus.B2000083

5. Mackenzie JS, Smith DW. COVID-19: a novel zoonotic disease caused by a coronavirus from China: what we know and what we don't. Microbiol Aust. (2020) 17:MA20013. doi: 10.1071/MA20013

6. Wang LF, Eaton BT. Bats, civets and the emergence of SARS. Curr Top Microbiol Immunol. (2007) 315:325-44. doi: 10.1007/978-3-540-70962-6_13

7. Sikkema RS, Farag E, Islam M, Atta M, Reusken C, Al-Hajri MM, et al. Global status of middle east respiratory syndrome coronavirus in dromedary camels: a systematic review. Epidemiol Infect. (2019) 147:e84. doi: 10.1017/s095026881800345x

8. Cyranoski D. The biggest mystery: what it will take to trace the coronavirus source. Nature. (2020). doi: 10.1038/d41586-020-01541-z

9. Boni MF, Lemey P, Jiang X, Lam TT-Y, Perry BW, Castoe TA, et al. Evolutionary origins of the SARS-CoV-2 sarbecovirus lineage responsible for the COVID-19 pandemic. Nat Microbiol. (2020) 5:140817. doi: 10.1038/s41564-020-0771-4

10. OIE, COVID-19 Portal. (2021). Available online at: https://www.oie.int/en/ scientific-expertise/specific-information-and-recommendations/questionsand-answers-on-2019novel-coronavirus/ (accessed January 21, 2021).

11. Koopmans MPG. SARS-CoV-2 and the human-animal interface: outbreaks on mink farms. Lancet Infect Dis. (2021) 21:18-9. doi: 10.1016/1473-3099(20)30912-9

12. Oude Munnink BB, Sikkema RS, Nieuwenhuijse DF, Molenaar RJ, Munger E, Molenkamp R, et al. Transmission of SARS-CoV-2 on mink farms between humans and mink and back to humans. Science. (2021) 371:172-7. doi: 10.1126/science.abe5901

13. Shereen MA, Khan S, Kazami A, Bashir N, Siddique R. COVID-19 infection: origin, transmission, and characteristics of human coronaviruses. J Advanc Res. (2020) 24:91-8. doi: 10.1016/j.jare.2020.03.005

14. Menachery VD, Graham RL, Baric RS. Jumping species-a mechanism for coronavirus persistence and survival. Curr Opin Virol. (2017) 23:1-7. doi: 10.1016/j.coviro.2017.01.002

15. Peck KM, Burch CL, Heise MT, Baric RS. Coronavirus host range expansion and middle east respiratory syndrome coronavirus emergence: biochemical mechanisms and evolutionary perspectives. Ann Rev Virol. (2015) 2:95117. doi: 10.1146/annurev-virology-100114-055029

16. Latinne A, Hu B, Olival KJ, Zhu G, Zhang L, Li H, et al. Origin and cross-species transmission of bat coronaviruses in China. bioRxiv : the Preprint Server for Biology. (2020). 2020.2005.2031.116061. doi: $10.1101 / 2020.05 .31 .116061$ provided critical feedback to improve the manuscript. All authors contributed to the table, literature search, contributed to the article, and approved the submitted version.

\section{FUNDING}

The publication of this article was funded by the Weill Cornell Medicine-Qatar Distributed eLibrary.

17. Lopes LR, de Mattos Cardillo G, Paiva PB. Molecular evolution and phylogenetic analysis of SARS-CoV-2 and hosts ACE2 protein suggest malayan pangolin as intermediary host. Braz J Microbiol. (2020) 51:15939. doi: 10.1007/s42770-020-00321-1

18. Schlottau K, Rissmann M, Graaf A, Schön J, Sehl J, Wylezich $\mathrm{C}$, et al. SARS-CoV-2 in fruit bats, ferrets, pigs, and chickens: an experimental transmission study. Lancet Microbe. (2020) 1:e218-25. doi: 10.1016/S2666-5247(20)30089-6

19. Bosco-Lauth AM, Hartwig AE, Porter SM, Gordy PW, Nehring M, Byas AD, et al. Experimental infection of domestic dogs and cats with SARS-CoV-2: pathogenesis, transmission, and response to reexposure in cats. Proc Natl Acad Sci USA. (2020) 117:26382-8. doi: 10.1073/pnas.2013102117

20. ProMed-mail. PRO/AH/EDR $>$ COVID-19 Update (70): China (Hong Kong) Animal, Cat, Pets \& Stock. (2020). Available online at: https://promedmail. org/promed-post/?id=20200402.7173286

21. Shi J, Wen Z, Zhong G, Yang H, Wang C, Huang B, et al. Susceptibility of ferrets, cats, dogs, and other domesticated animals to SARS-coronavirus 2. Science. (2020) 368:1016-20. doi: 10.1126/science.abb7015

22. ProMed-mail. PRO/AH/EDR $>$ COVID-19 update (88): Germany, animal, research, pig, chicken, bat, ferret. (2020)

23. Sia SF, Yan L-M, Chin AWH, Fung K, Choy K-T, Wong AYL, et al Pathogenesis and transmission of SARS-CoV-2 in golden hamsters. Nature. (2020) 583:834-8. doi: 10.1038/s41586-020-2342-5

24. Muñoz-Fontela C, Dowling WE, Funnell SGP, Gsell PS, Riveros-Balta AX, Albrecht RA, et al. Animal models for COVID-19. Nature. (2020) 586:50915. doi: 10.1038/s41586-020-2787-6

25. ProMed-mail. PRO/AH/EDR $>$ COVID-19 Update (169): Netherlands (NB) Animal, Farmed Mink, Spread, Rabbit Susp. Brookline, MA (2020). Available online at: https://promedmail.org/promed-post/?id=20200509. 7316646 (accessed May 18, 2020).

26. ProMed-mail. PRO/AH/EDR $>$ COVID-19 Update (76): China (HU) Animal, Cat, Owned, Stray, Seropositive. (2020). Available online at: https:// promedmail.org/promed-post/?id=20200403.7179946

27. United States Department of Agriculture. USDA Statement on the Confirmation of COVID-19 in a Tiger in New York. (ed.) A.a.P.H.I. Service. (Office of Adjudication, 1400 Independence Ave., SW, Washington, DC: USDA, Office of the Assistant Secretary for Civil Rights) (2020)

28. Zhang $\mathrm{P}$, Zhu L, Cai J, Lei F, Qin J-J, Xie J, et al. Association of inpatient use of angiotensin-converting enzyme inhibitors and angiotensin II receptor blockers with mortality among patients with hypertension hospitalized with COVID-19. Circul Res. (2020) 126:1671-81. doi: 10.1161/CIRCRESAHA.120.317134

29. ProMed-mail. PRO/AH/EDR > COVID-19 Update (84): USA, Animal, Tiger. (2020) Available online at: https://promedmail.org/promed-post/?id= 20200406.7191352

30. ProMed-mail. PRO/AH/EDR > COVID-19 Update (85): USA (NY) Animal, Tiger, OIE. (2020) Available online at: https://promedmail.org/promedpost/?id=20200406.7191480

31. ProMed-mail. $P R O / A H / E D R>C O V I D-19$ Update (135): Netherlands (NB) Animal, Farmed Mink. (2020) Available online at: https://promedmail.org/ promed-post/?id=20200427.7272289

32. ProMed-mail. PRO/AH/EDR $>$ COVID-19 Update (189): Netherlands (NB) Animal, Farmed Mink, Research, Cat, Dog. (2020) Available online at: https:// promedmail.org/promed-post $/$ id=20200517.7344274 
33. World Health Organization. Coronavirus Disease 2019 (COVID-19): Situation Report. Geneva: World Health Organization (2020).

34. World Health Organization. "COVID-19: Virtual Press Conference" Geneva (2020). Available online: https://www.who.int/docs/default-source/ coronaviruse/covid-19-virtual-press-conference-- - 10-august-at-12-pmcest.pdf?sfvrsn=46fd5bbd_0 (accessed September 10, 2020).

35. WHO. Origins of the SARS-CoV-2 Virus. (2021). Available online at: https:// www.who.int/health-topics/coronavirus/origins-of-the-virus (accessed January 21, 2021).

36. Leclerc Q, Fuller NM, Kinght LE, Funk S, Kinght GM. What settings have been linked to SARS-CoV-2 transmission clusters? Welcome Open Res. (2020) 5:83. doi: 10.12688/wellcomeopenres.15889.2

37. Liu M, Caputi TL, Dredze M, Kesselheim AS, Ayers JW. Internet searches for unproven COVID-19 therapies in the United States. JAMA Intern Med. (2020) 180:1116-8. doi: 10.1001/jamainternmed.2020.1764

38. van Doremalen N, Bushmaker T, Morris DH, Holbrook MG, Gamble A, Williamson BN, et al. Aerosol and surface stability of SARS-CoV2 as compared with SARS-CoV-1. N. Engl. J. Med. (2020) 382:15647. doi: 10.1056/NEJMc2004973

39. Zhang Q, Zhang H, Huang K, Yang Y, Hui X, Gao J, et al. SARS-CoV-2 neutralizing serum antibodies in cats: a serological investigation. bioRxiv. (2020) 2020.2004.2001.021196. doi: 10.1101/2020.04.01.021196

40. Zhang R, Li Y, Zhang AL, Wang Y, Molina MJ. Identifying airborne transmission as the dominant route for the spread of COVID-19. Proc Natl Acad Sci USA. (2020) 117:14857-63. doi: 10.1073/pnas.2009637117

41. Morawska L, Milton DK. It is time to address airborne transmission of coronavirus disease 2019 (COVID-19). Clin Infect Dis. (2020) 71:231113. doi: $10.1093 /$ cid/ciaa939

42. Chen N, Zhou M, Dong X, Qu J, Gong F, Han Y, et al. Epidemiological and clinical characteristics of 99 cases of 2019 novel coronavirus pneumonia in Wuhan, China: a descriptive study. Lancet. (2020) 395:50713. doi: 10.1016/s0140-6736(20)30211-7

43. Neuman BW, Adair BD, Yoshioka C, Quispe JD, Orca G, Kuhn P, et al. Supramolecular architecture of severe acute respiratory syndrome coronavirus revealed by electron cryomicroscopy. J Virol. (2006) 80:791828. doi: 10.1128/jvi.00645-06

44. Bárcena M, Oostergetel GT, Bartelink W, Faas FG, Verkleij A, Rottier PJ, et al. Cryo-electron tomography of mouse hepatitis virus: insights into the structure of the coronavirion. Proc Natl Acad Sci USA. (2009) 106:5827. doi: 10.1073/pnas.0805270106

45. Wan Y, Shang J, Graham R, Baric RS, Li F. Receptor recognition by the novel coronavirus from Wuhan: an analysis based on decadelong structural studies of SARS coronavirus. J Virol. (2020) 94:e0012720. doi: 10.1128/JVI.00127-20

46. Lucchese G. Epitopes for a 2019-nCoV vaccine. Cell Mol Immunol. (2020) 17:539-40. doi: 10.1038/s41423-020-0377-z

47. De Maio F, Lo Cascio E, Babini G, Sali M, Della Longa S, Tilocca B, et al. Improved binding of SARS-CoV-2 envelope protein to tight junctionassociated PALS1 could play a key role in COVID-19 pathogenesis. Microb Infect. (2020) 22:592-7. doi: 10.1016/j.micinf.2020.08.006

48. McBride R, van Zyl M, Fielding BC. The coronavirus nucleocapsid is a multifunctional protein. Viruses. (2014) 6:2991-3018. doi: 10.3390/v6082991

49. Burkard C, Verheije MH, Wicht O, van Kasteren SI, van Kuppeveld FJ, Haagmans BL, et al. Coronavirus cell entry occurs through the endo/lysosomal pathway in a proteolysis-dependent manner. PLoS Pathog. (2014) 10:e1004502. doi: 10.1371/journal.ppat.1004502

50. Millet JK, Whittaker GR. Host cell proteases: critical determinants of coronavirus tropism and pathogenesis. Virus Res. (2015) 202:12034. doi: 10.1016/j.virusres.2014.11.021

51. Tortorici MA, Veesler D. Structural insights into coronavirus entry. Adv Virus Res. (2019) 105:93-116. doi: 10.1016/bs.aivir.2019.08.002

52. Madu IG, Roth SL, Belouzard S, Whittaker GR. Characterization of a highly conserved domain within the severe acute respiratory syndrome coronavirus spike protein S2 domain with characteristics of a viral fusion peptide. J Virol. (2009) 83:7411-21. doi: 10.1128/jvi.00079-09

53. Glowacka I, Bertram S, Müller MA, Allen P, Soilleux E, Pfefferle S, et al. Evidence that TMPRSS2 activates the severe acute respiratory syndrome coronavirus spike protein for membrane fusion and reduces viral control by the humoral immune response. J Virol. (2011) 85:412234. doi: 10.1128/JVI.02232-10

54. Hoffmann M, Kleine-Weber H, Schroeder S, Krüger N, Herrler T, Erichsen $\mathrm{S}$, et al. SARS-CoV-2 cell entry depends on ACE2 and TMPRSS2 and is blocked by a clinically proven protease inhibitor. Cell. (2020) 181:27180.e8. doi: 10.1016/j.cell.2020.02.052

55. Walls AC, Park Y-J, Tortorici MA, Wall A, McGuire AT, Veesler D. Structure, function, and antigenicity of the SARS-CoV-2 spike glycoprotein. Cell. (2020) 181:281-92.e286. doi: 10.1016/j.cell.2020.02.058

56. GISAID. (2010). Available online at: https://www.epicov.org (accessed September 10, 2020).

57. Pachetti M, Marini B, Benedetti F, Giudici F, Mauro E, Storici P, et al. Emerging SARS-CoV-2 mutation hot spots include a novel RNA-dependent-RNA polymerase variant. J Transl Med. (2020) 18:179. doi: 10.1186/s12967-020-02344-6

58. Angeletti S, Benvenuto D, Bianchi M, Giovanetti M, Pascarella S, Ciccozzi M. COVID-2019: the role of the nsp2 and nsp3 in its pathogenesis. J Med Virol. (2020) 92:584-8. doi: 10.1002/jmv.25719

59. Callaway E. The coronavirus is mutating - does it matter? Nature. (2020) 585:174-7. doi: 10.1038/d41586-020-02544-6

60. Zhu N, Zhang D, Wang W, Li X, Yang B, Song J, et al. A novel coronavirus from patients with pneumonia in China, 2019. N Engl J Med. (2020) 382:72733. doi: 10.1056/NEJMoa2001017

61. Elbe S, Buckland-Merrett G. Data, disease and diplomacy: GISAID's innovative contribution to global health. Glob Chall. (2017) 1:3346. doi: $10.1002 /$ gch 2.1018

62. Gussow AB, Auslander N, Faure G, Wolf YI, Zhang F, Koonin EV. Genomic determinants of pathogenicity in SARS-CoV-2 and other human coronaviruses. Proc Natl Acad Sci USA. (2020) 117:151939. doi: 10.1073/pnas.2008176117

63. Korber B, Fischer WM, Gnanakaran S, Yoon H, Theiler J, Abfalterer $\mathrm{W}$, et al. Tracking changes in SARS-CoV-2 spike: evidence that D614G increases infectivity of the COVID-19 virus. Cell. (2020) 182:81227.e819. doi: 10.1016/j.cell.2020.06.043

64. Koyama T, Platt D, Parida L. Variant analysis of COVID-19 genomes. Bull World Health Organ. (2020) 98:495-504. doi: 10.2471/BLT.20.253591

65. Rambaut A, Loman N, Pybus O, Barclay W, Barrett J, Carabelli A, et al. Preliminary genomic characterisation of an emergent SARS-CoV-2 lineage in the UK defined by a novel set of spike mutations. ARTIC Netw. (2020). Available online at: https://virological.org/t/preliminarygenomic-characterisation-of-an-emergent-sars-cov-2-lineage-in-the-ukdefined-by-a-novel-set-of-spike-mutations/563 (accessed January 5, 2021).

66. World Health Organization. SARS-CoV-2 Variants. (2020) Available online at: https://www.who.int/csr/don/31-december-2020-sars-cov2-variants/en/ (accessed January 05, 2021).

67. Centers for Disease Control Prevention. Interim: Implications of the Emerging SARS-CoV-2 Variant VOC 202012/01. U.S. Department of Health \& Human Services. (2020) Available online at: https://www.cdc. gov/coronavirus/2019-ncov/more/scientific-brief-emerging-variant.html (accessed January 05, 2021).

68. Kupeferschmidt K. Mutant coronavirus in the United Kingdom sets off alarms, but its importance remains unclear. Science. (2020). Available online at: https://www.sciencemag.org/news/2020/12/mutant-coronavirus- unitedkingdom-sets-alarms-its-importance-remains-unclear (accessed January 5, 2021).

69. Kemp SA, Collier DA, Datir R, Ferreira IATM, Gayed S, Jahun A, et al. Neutralising antibodies drive Spike mediated SARS-CoV-2 evasion. medRxiv. (2020) 2012.2005.20241927. doi: 10.1101/2020.12.05.20241927

70. Wise J. Covid-19: new coronavirus variant is identified in UK. BMJ. (2020) 371:m4857. doi: 10.1136/bmj.m4857

71. Simon AK, Hollander GA, McMichael A. Evolution of the immune system in humans from infancy to old age. Proc R Soc B Biol Sci. (2015) 282:20143085. doi: $10.1098 /$ rspb.2014.3085

72. Tegally H, Wilkinson E, Giovanetti M, Iranzadeh A, Fonseca V, Giandhari $\mathrm{J}$, et al. Emergence and rapid spread of a new severe acute respiratory syndrome-related coronavirus 2 (SARS-CoV-2) lineage with multiple spike mutations in South Africa. medRxiv. (2020) 2020.2012.2021.20248640. doi: $10.1101 / 2020.12 .21 .20248640$ 
73. Garry RF. Mutations Arising in SARS-CoV-2 Spike on Sustained Humanto-Human Transmission and Human-to-Animal Passage. (2021) Available online at: https://virological.org/t/mutations-arising-in-sars-cov-2-spikeon-sustained-human-to-human-transmission-and-human-to-animalpassage/578 (accessed January 13, 2021).

74. Davies NG, Barnard RC, Jarvis CI, Kucharski AJ, Munday J, Pearson CAB, et al. Estimated transmissibility and severity of novel SARS-CoV-2 Variant of Concern 202012/01 in England. medRxiv. (2020) 2020.2012.2024.20248822. doi: $10.1101 / 2020.12 .24 .20248822$

75. Xie X, Zou J, Fontes-Garfias CR, Xia H, Swanson KA, Cutler M, et al. Neutralization of N501Y mutant SARS-CoV-2 by BNT162b2 vaccine-elicited sera. bioRxiv. (2021) 2021.2001.2007.425740. doi: 10.1101/2021.01.07.425740

76. Shang J, Wan Y, Luo C, Ye G, Geng Q, Auerbach A, et al. Cell entry mechanisms of SARS-CoV-2. Proc Natl Acad Sci USA. (2020) 117:1172734. doi: 10.1073/pnas.2003138117

77. Chen X, Li R, Pan Z, Qian C, Yang Y, You R, et al. Human monoclonal antibodies block the binding of SARS-CoV-2 spike protein to angiotensin converting enzyme 2 receptor. Cell Mol Immunol. (2020) 17:647-9. doi: 10.1038/s41423-020-0426-7

78. Wang F, Nie J, Wang H, Zhao Q, Xiong Y, Deng L, et al. Characteristics of peripheral lymphocyte subset alteration in COVID-19 pneumonia. J Infect Dis. (2020) 221:1762-9. doi: 10.1093/infdis/jiaa150

79. Guo T, Fan Y, Chen M, Wu X, Zhang $\mathrm{L}, \mathrm{He} \mathrm{T}$, et al. Cardiovascular implications of fatal outcomes of patients with coronavirus disease 2019 (COVID-19). JAMA Cardiol. (2020) 5:811-8. doi: 10.1001/jamacardio.2020.1017

80. Hamming I, Timens W, Bulthuis M, Lely A, Navis G, van Goor H. Tissue distribution of ACE2 protein, the functional receptor for SARS coronavirus. A first step in understanding SARS pathogenesis. J Pathol. (2004) 203:6317. doi: $10.1002 /$ path.1570

81. Sriram K, Loomba R, Insel PA. Targeting the renin-angiotensin signaling pathway in COVID-19: unanswered questions, opportunities, and challenges. Proc Natl Acad Sci USA. (2020) 117:29274-82. doi: 10.1073/pnas.2009875117

82. Gupta A, Madhavan MV, Sehgal K, Nair N, Mahajan S, Sehrawat TS, et al. Extrapulmonary manifestations of COVID-19. Nat Med. (2020) 26:101732. doi: 10.1038/s41591-020-0968-3

83. Singh AK, Gupta R, Ghosh A, Misra A. Diabetes in COVID-19: prevalence, pathophysiology, prognosis and practical considerations. Diabetes Metab Syndr Clin Res Rev. (2020) 14:303-10. doi: 10.1016/j.dsx.2020.04.004

84. Hill MA, Sowers JR, Mantzoros CS. Commentary: COVID19 and obesity pandemics converge into a syndemic requiring urgent and multidisciplinary action. Metab Clin Exp. (2020) 114:154408. doi: 10.1016/j.metabol.2020.154408

85. Nicholson TW, Talbot NP, Nickol A, Chadwick AJ, Lawton O. Respiratory failure and non-invasive respiratory support during the covid-19 pandemic: an update for re-deployed hospital doctors and primary care physicians. BMJ. (2020) 369:m2446. doi: 10.1136/bmj.m2446

86. Bradley BT, Maioli H, Johnston R, Chaudhry I, Fink SL, Xu H, et al. Histopathology and ultrastructural findings of fatal COVID-19 infections in Washington State: a case series. Lancet. (2020) 396:32032. doi: 10.1016/s0140-6736(20)31305-2

87. Bonow RO, O'Gara PT, Yancy CW. Cardiology and COVID-19. JAMA. (2020) 324:1131-2. doi: 10.1001/jama.2020.15088

88. Gao J, Tian Z, Yang X. Breakthrough: chloroquine phosphate has shown apparent efficacy in treatment of COVID-19 associated pneumonia in clinical studies. Biosci Trends. (2020) 14:72-3. doi: 10.5582/bst.2020.01047

89. Huertas A, Montani D, Savale L, Pichon J, Tu L, Parent F, et al. Endothelial cell dysfunction: a major player in SARS-CoV-2 infection (COVID-19)? Eur Respir J. (2020) 56:2001634. doi: 10.1183/13993003.01634-2020

90. Tang N, Li D, Wang X, Sun Z. Abnormal coagulation parameters are associated with poor prognosis in patients with novel coronavirus pneumonia. J Thromb Haemostasis. (2020) 18:844-7. doi: 10.1111/jth.14768

91. Barnes GD, Burnett A, Allen A, Blumenstein M, Clark NP, Cuker A, et al. Thromboembolism and anticoagulant therapy during the COVID19 pandemic: interim clinical guidance from the anticoagulation forum. $J$ Thromb Thrombolysis. (2020) 50:72-81. doi: 10.1007/s11239-020-02138-z
92. Connors JM, Levy JH. COVID-19 and its implications for thrombosis and anticoagulation. Blood. (2020) 135:2033-40. doi: 10.1182/blood.2020006000

93. National Institutes of Health. Antithrombotic Therapy in Patients with COVID-19. (2020) Available online at: https://www. covid19treatmentguidelines.nih.gov/adjunctive-therapy/antithrombotictherapy (accessed January 02, 2021).

94. Piazza G, Morrow DA. Diagnosis, management, and pathophysiology of arterial and venous thrombosis in COVID-19. JAMA. (2020) 324:25489. doi: 10.1001 /jama.2020.23422

95. Hughes S. COVID-19 anticoagulation trials 'paused' for futility, safety. Medscape. (2020). Available online at: https://www.medscape.com/ viewarticle/943085 (accessed January 5, 2021)

96. Sinha P, Matthay MA, Calfee CS. Is a "Cytokine storm" relevant to COVID-19? JAMA Intern Med. (2020) 180:11524. doi: 10.1001/jamainternmed.2020.3313

97. Sterne JAC, Murthy S, Diaz JV, Slutsky AS, Villar J, Angus DC, et al. Association between administration of systemic corticosteroids and mortality among critically ill patients With COVID-19: a meta-analysis. JAMA. (2020) 324:1330-41. doi: 10.1001/jama.2020.17023

98. Lan S-H, Lai C-C, Huang H-T, Chang S-P, Lu L-C, Hsueh P-R. Tocilizumab for severe COVID-19: a systematic review and meta-analysis. Int $J$ Antimicrob Agents. (2020) 56:106103. doi: 10.1016/j.ijantimicag.2020.106103

99. Hermine O, Mariette X, Tharaux PL, Resche-Rigon M, Porcher R, Ravaud P. Effect of tocilizumab vs usual care in adults hospitalized with COVID-19 and moderate or severe pneumonia: a randomized clinical trial. JAMA Intern Med. (2021) 181:32-40. doi: 10.1001/jamainternmed.2020.6820

100. Parr JB. Time to reassess tocilizumab's role in COVID-19 pneumonia. JAMA Intern Med. (2021) 181:12-5. doi: 10.1001/jamainternmed.2020.6557

101. Grifoni A, Weiskopf D, Ramirez SI, Mateus J, Dan JM, Moderbacher CR, et al. Targets of $\mathrm{T}$ cell responses to SARS-CoV-2 coronavirus in humans with COVID-19 disease and unexposed individuals. Cell. (2020) 181:1489501.e1415. doi: 10.1016/j.cell.2020.05.015

102. Wu L-P, Wang N-C, Chang Y-H, Tian X-Y, Na D-Y, Zhang L-Y, et al. Duration of antibody responses after severe acute respiratory syndrome. Emerg Infect Dis J. (2007) 13:1562-4. doi: 10.3201/eid1310.070576

103. Chen P, Nirula A, Heller B, Gottlieb RL, Boscia J, Morris J, et al. SARS-CoV2 neutralizing antibody LY-CoV555 in outpatients with covid-19. N Engl J Med. (2020). 384:229-37. doi: 10.1056/NEJMoa2029849

104. Moderbacher CR, Ramirez SI, Dan JM, Grifoni A, Hastie KM, Weiskopf D, et al. Antigen-specific adaptive immunity to SARS-CoV-2 in acute COVID19 and associations with age and disease severity. Cell. (2020) 183:9961012.e1019. doi: 10.1016/j.cell.2020.09.038

105. Frieman M, Heise M, Baric R. SARS coronavirus and innate immunity. Virus Res. (2008) 133:101-12. doi: 10.1016/j.virusres.2007.03.015

106. Alfuwaires M, Altaher A, Kandeel M. Molecular dynamic studies of interferon and innate immunity resistance in MERS CoV non-structural protein 3. Biol Pharm Bull. (2017) 40:345-51. doi: 10.1248/bpb.b16-00870

107. Hosseini A, Hashemi V, Shomali N, Asghari F, Gharibi T, Akbari M, et al. Innate and adaptive immune responses against coronavirus. Biomed Pharmacother. (2020) 132:110859. doi: 10.1016/j.biopha.2020.110859

108. Dixit E, Kagan JC. Intracellular pathogen detection by RIG-I-like receptors. Adv Immunol. (2013) 117:99-125. doi: 10.1016/b978-0-12-410524-9.00004-9

109. Kindler E, Thiel V. SARS-CoV and IFN: too little, too late. Cell Host Microbe. (2016) 19:139-41. doi: 10.1016/j.chom.2016.01.012

110. Blanco-Melo D, Nilsson-Payant BE, Liu W-C, Uhl S, Hoagland D, Møller $\mathrm{R}$, et al. Imbalanced host response to SARS-CoV-2 drives development of COVID-19. Cell. (2020) 181:1036-45.e1039. doi: 10.1016/j.cell.2020.04.026

111. Lokugamage KG, Hage A, de Vries M, Valero-Jimenez AM, Schindewolf C, Dittmann M, et al. Type I interferon susceptibility distinguishes SARS-CoV2 from SARS-CoV. J Virol. (2020) 94:e01410-20. doi: 10.1128/jvi.01410-20

112. Mantlo E, Bukreyeva N, Maruyama J, Paessler S, Huang C. Antiviral activities of type I interferons to SARS-CoV-2 infection. Antiviral Res. (2020) 179:104811. doi: 10.1016/j.antiviral.2020.104811

113. Stanifer ML, Kee C, Cortese M, Zumaran CM, Triana S, Mukenhirn $\mathrm{M}$, et al. Critical role of type III interferon in controlling SARS-CoV-2 infection in human intestinal epithelial cells. Cell Rep. (2020) 32:107863. doi: 10.1016/j.celrep.2020.107863 
114. Huang IC, Bailey CC, Weyer JL, Radoshitzky SR, Becker MM, Chiang JJ, et al. Distinct patterns of IFITM-mediated restriction of filoviruses, SARS coronavirus, and influenza A virus. PLoS Pathog. (2011) 7:e1001258. doi: 10.1371/journal.ppat.1001258

115. Pfaender S, Mar KB, Michailidis E, Kratzel A, Hirt D, V'Kovski P, et al. LY6E impairs coronavirus fusion and confers immune control of viral disease. Nat Microbiol. (2020) 5:1330-9. doi: 10.1038/s41564-020-0769-y

116. Zhao S, Ling K, Yan H, Zhong L, Peng X, Yao S, et al. Anesthetic management of patients with suspected or confirmed 2019 novel coronavirus infection during emergency procedures. J Cardiothorac Vasc Anesth. (2020) 34:112531. doi: $10.1053 /$ j.jvca.2020.02.039

117. Thiel V, Weber F. Interferon and cytokine responses to SARScoronavirus infection. Cytokine Growth Factor Rev. (2008) 19:121-32. doi: 10.1016/j.cytogfr.2008.01.001

118. Hu W, Yen YT, Singh S, Kao CL, Wu-Hsieh BA. SARS-CoV regulates immune function-related gene expression in human monocytic cells. Viral Immunol. (2012) 25:277-88. doi: 10.1089/vim.2011.0099

119. Wathelet MG, Orr M, Frieman MB, Baric RS. Severe acute respiratory syndrome coronavirus evades antiviral signaling: role of nsp1 and rational design of an attenuated strain. J Virol. (2007) 81:1162033. doi: 10.1128/jvi.00702-07

120. Minakshi R, Padhan K, Rani M, Khan N, Ahmad F, Jameel S. The SARS coronavirus 3a protein causes endoplasmic reticulum stress and induces ligand-independent downregulation of the type 1 interferon receptor. PLoS ONE. (2009) 4:e8342. doi: 10.1371/journal.pone.0008342

121. Siu KL, Kok KH, Ng MH, Poon VK, Yuen KY, Zheng BJ, et al. Severe acute respiratory syndrome coronavirus $\mathrm{M}$ protein inhibits type I interferon production by impeding the formation of TRAF3.TANK.TBK1/IKKepsilon complex. J Biol Chem. (2009) 284: 16202-9. doi: 10.1074/jbc.M109.008227

122. Cameron MJ, Kelvin AA, Leon AJ, Cameron CM, Ran L, Xu L, et al. Lack of innate interferon responses during SARS coronavirus infection in a vaccination and reinfection ferret model. PLOS ONE. (2012) 7:e45842. doi: 10.1371/journal.pone.0045842

123. Hadjadj J, Yatim N, Barnabei L, Corneau A, Boussier J, Smith $\mathrm{N}$, et al. Impaired type $\mathrm{I}$ interferon activity and inflammatory responses in severe COVID-19 patients. Science. (2020) 369:71824. doi: $10.1126 /$ science.abc6027

124. Hsueh P-R, Huang L-M, Chen P-J, Kao C-L, Yang P-C. Chronological evolution of IgM, IgA, IgG and neutralisation antibodies after infection with SARS-associated coronavirus. Clin Microbiol Infect. (2004) 10:10626. doi: 10.1111/j.1469-0691.2004.01009.x

125. Burbelo PD, Riedo FX, Morishima C, Rawlings S, Smith D, Das S, et al. Sensitivity in detection of antibodies to nucleocapsid and spike proteins of severe acute respiratory syndrome coronavirus 2 in patients with coronavirus disease 2019. J Infect Dis. (2020) 222:206-13. doi: 10.1093/infdis/jiaa273

126. Long Q-X, Tang X-J, Shi Q-L, Li Q, Deng H-J, Yuan J, et al. Clinical and immunological assessment of asymptomatic SARS-CoV-2 infections. Nat Med. (2020) 26:1200-4. doi: 10.1038/s41591-020-0965-6

127. Suthar MS, Zimmerman MG, Kauffman RC, Mantus G, Linderman SL, Hudson WH, et al. Rapid generation of neutralizing antibody responses in COVID-19 patients. Cell Rep Med. (2020) 1:100040. doi: 10.1016/j.xcrm.2020.100040

128. Okba NMA, Muller MA, Li W, Wang C, GeurtsvanKessel CH, Corman $\mathrm{VM}$, et al. Severe acute respiratory syndrome coronavirus 2-specific antibody responses in coronavirus disease patients. Emerg Infect Dis. (2020) 26:147888. doi: 10.3201/eid2607.200841

129. Woelfel R, Corman VM, Guggemos W, Seilmaier M, Zange S, Mueller MA, et al. Virological assessment of hospitalized patients with COVID-2019. Nature. (2020) 581:465-9. doi: 10.1038/s41586-020-2196-x

130. Martínez-Fleta P, Alfranca A, González-Álvaro I, Casasnovas JM, FernándezSoto D, Esteso G, et al. SARS-CoV-2 cysteine-like protease antibodies can be detected in serum and saliva of COVID-19-seropositive individuals. $J$ Immunol. (2020) 205:3130-40. doi: 10.4049/jimmunol.2000842

131. Poland GA, Ovsyannikova IG, Kennedy RB. SARS-CoV-2 immunity: review and applications to phase 3 vaccine candidates. Lancet. (2020) 396:1595606. doi: 10.1016/S0140-6736(20)32137-1

132. Adams ER, Ainsworth M, Anand R, Andersson MI, Auckland K, Baillie JK, et al. Antibody testing for COVID-19: A report from the National COVID
Scientific Advisory Panel. medRxiv. (2020) 2020.2004.2015.20066407. doi: 10.1101/2020.04.15.20066407

133. Ibarrondo FJ, Fulcher JA, Goodman-Meza D, Elliott J, Hofmann C, Hausner MA, et al. Rapid decay of anti-SARS-CoV-2 antibodies in persons with mild covid-19. N Engl J Med. (2020) 383:1085-7. doi: 10.1056/NEJMc2025179

134. Röltgen K, Wirz OF, Stevens BA, Powell AE, Hogan CA, Najeeb J, et al. (2020). SARS-CoV-2 antibody responses correlate with resolution of RNAemia but are short-lived in patients with mild Illness. medRxiv. 2020.08.15.20175794. doi: 10.1101/2020.08.15.20175794

135. Tan W, Lu Y, Zhang J, Wang J, Dan Y, Tan Z, et al. Viral kinetics and antibody responses in patients with COVID-19. medRxiv. (2020) 2020.2003.2024.20042382. doi: 10.1101/2020.03.24.20042382

136. Callow KA, Parry HF, Sergeant M, Tyrrell DAJ. The time course of the immune response to experimental coronavirus infection of man. Epidemiol Infect. (1990) 105:435-46. doi: 10.1017/S0950268800048019

137. Zeng H, Xu C, Fan J, Tang Y, Deng Q, Zhang W, et al. Antibodies in infants born to mothers with COVID-19 pneumonia. JAMA. (2020) 323:18489. doi: 10.1001/jama.2020.4861

138. Lumley SF, O'Donnell D, Stoesser NE, Matthews PC, Howarth A, Hatch SB, et al. Antibody status and incidence of SARS-CoV-2 infection in health care workers. N Eng J Med. (2020) NEJMoa2034545. doi: 10.1056/NEJMoa2034545

139. Ferguson N, Laydon D, Nedjati-Gilani G, Imai N, Ainslie K, Baguelin $\mathrm{M}$, et al. Report 9: Impact of Non-pharmaceutical Interventions (NPIs) to Reduce COVID-19 Mortality and Healthcare Demand. London, UK. (2020). doi: $10.25561 / 77482$

140. Shen C, Wang Z, Zhao F, Yang Y, Li J, Yuan J, et al. Treatment of 5 critically ill patients with COVID-19 with convalescent plasma. JAMA. (2020) 323:15829. doi: 10.1001/jama.2020.4783

141. Roback JD, Guarner J. Convalescent plasma to treat COVID-19: possibilities and challenges. JAMA. (2020) 323:1561-2. doi: 10.1001/jama.2020.4940

142. Libster R, Pérez Marc G, Wappner D, Coviello S, Bianchi A, Braem V, et al. Early high-titer plasma therapy to prevent severe Covid-19 in older adults. $N$ Engl J Med. (2021) NEJMoa2033700. doi: 10.1056/NEJMoa2033700

143. de Vries RD. SARS-CoV-2-specific T-cells in unexposed humans: presence of cross-reactive memory cells does not equal protective immunity. Signal Transd Target Ther. (2020) 5:224. doi: 10.1038/s41392-020-00338-w

144. Sekine T, Perez-Potti A, Rivera-Ballesteros O, Strålin K, Gorin J-B, Olsson A, et al. Robust $\mathrm{T}$ cell immunity in convalescent individuals with asymptomatic or mild COVID-19. Cell. (2020) 183:158-68.e14. doi: 10.1016/j.cell.2020.08.017

145. Lu W, Mehraj V, Vyboh K, Cao W, Li T, Routy J-P. CD4:CD8 ratio as a frontier marker for clinical outcome, immune dysfunction and viral reservoir size in virologically suppressed HIV-positive patients. J Int AIDS Soc. (2015) 18:20052. doi: 10.7448/IAS.18.1.20052

146. Peng Y, Mentzer AJ, Liu G, Yao X, Yin Z, Dong D, et al. Broad and strong memory CD4+ and CD8 $+\mathrm{T}$ cells induced by SARS-CoV-2 in UK convalescent individuals following COVID-19. Nat Immunol. (2020) 21:1336-45. doi: 10.1038/s41590-020-0782-6

147. Sattler A, Angermair S, Stockmann H, Heim KM, Khadzhynov D, Treskatsch S, et al. SARS-CoV-2-specific T cell responses and correlations with COVID-19 patient predisposition. J Clin Invest. (2020) 130:647789. doi: 10.1172/jci140965

148. Chen G, Wu D, Guo W, Cao Y, Huang D, Wang H, et al. Clinical and immunological features of severe and moderate coronavirus disease 2019. J Clin Invest. (2020) 130:2620-9. doi: 10.1172/JCI137244

149. Bastard P, Rosen LB, Zhang Q, Michailidis E, Hoffmann HH, Zhang $\mathrm{Y}$, et al. Autoantibodies against type I IFNs in patients with lifethreatening COVID-19. Science. (2020) 370:eabd4585. doi: 10.1126/science. abd 4585

150. Le Bert $\mathrm{N}$, Tan AT, Kunasegaran K, Tham CYL, Hafezi M, Chia A, et al. SARS-CoV-2-specific $\mathrm{T}$ cell immunity in cases of COVID-19 and SARS, and uninfected controls. Nature. (2020) 584:457-62. doi: 10.1038/s41586-020-2550-z

151. Gallais F, Velay A, Wendling M-J, Nazon C, Wendling M-J, Partisani M, et al. Intrafamilial exposure to SARS-CoV-2 associated with cellular immune response without seroconversion, France. Emerg Infect Dis. (2020) 27:11321. doi: $10.3201 /$ eid 2701.203611 
152. Yonker LM, Neilan AM, Bartsch Y, Patel AB, Regan J, Arya P, et al. Pediatric severe acute respiratory syndrome coronavirus 2 (SARS-CoV-2): clinical presentation, infectivity, and immune responses. J Pediatr. (2020) 227:4552.e5. doi: 10.1016/j.jpeds.2020.08.037

153. Schuez-Havupalo L, Toivonen L, Karppinen S, Kaljonen A, Peltola V. Daycare attendance and respiratory tract infections: a prospective birth cohort study. BMJ Open. (2017) 7:e014635. doi: 10.1136/bmjopen-2016-014635

154. Bialek S, Gierke R, Hughes M, McNamara L, Pilishvili T, Skoff T. Coronavirus disease 2019 in children - United States, February 12April 2, 2020. MMWR Morbidity Mortal Wkly Rep. (2020) 69:4226. doi: 10.15585/mmwr.mm6914e4

155. Parri N, Lenge $M$, Buonsenso D. Children with covid-19 in pediatric emergency departments in Italy. $N$ Engl J Med. (2020) 383:18790. doi: 10.1056/NEJMc2007617

156. Lu X, Zhang L, Du H, Zhang J, Li YY, Qu J, et al. SARS-CoV-2 infection in children. N Engl J Med. (2020) 382:1663-5. doi: 10.1056/NEJMc2005073

157. Posfay-Barbe KM, Wagner N, Gauthey M, Moussaoui D, Loevy N, Diana A, et al. COVID-19 in children and the dynamics of infection in families. Pediatrics. (2020) 146:e20201576. doi: 10.1542/peds.2020-1576

158. Tagarro A, Epalza C, Santos M, Sanz-Santaeufemia FJ, Otheo E, Moraleda C, et al. Screening and severity of coronavirus disease 2019 (COVID-19) in children in madrid, Spain. JAMA Pediatr. (2020) doi: 10.1001/jamapediatrics.2020.1346

159. Heald-Sargent T, Muller WJ, Zheng X, Rippe J, Patel AB, Kociolek LK. Age-related differences in nasopharyngeal severe acute respiratory syndrome coronavirus 2 (SARS-CoV-2) levels in patients with mild to moderate coronavirus disease 2019 (COVID-19). JAMA Pediatr. (2020) 174:9023. doi: 10.1001/jamapediatrics.2020.3651

160. American Academy of Pediatrics. Children and COVID-19: State Data Report. United States of America. (2020) Available online at: https://downloads.aap.org/AAP/PDF/AAP\%20and\%20CHA\%20\%20Children\%20and\%20COVID-19\%20State\%20Data\%20Report\%207.30. 20\%20FINAL.pdf (accessed October 2, 2020).

161. Dong Y, Mo X, Hu Y, Qi X, Jiang F, Jiang Z, et al. Epidemiology of COVID-19 among children in China. Pediatrics. (2020) 145:e20200702. doi: 10.1542/peds.2020-0702

162. van der Made CI, Simons A, Schuurs-Hoeijmakers J, van den Heuvel G, Mantere T, Kersten S, et al. Presence of genetic variants among young men with severe COVID-19. JAMA. (2020) 324:663-73. doi: 10.1001/jama.2020.13719

163. Götzinger F, Santiago-García B, Noguera-Julián A, Lanaspa M, Lancella L, Calò Carducci FI, et al. COVID-19 in children and adolescents in Europe: a multinational, multicentre cohort study. Lancet Child Adolesc Health. (2020) 4:653-61. doi: 10.1016/S2352-4642(20)30177-2

164. Shekerdemian LS, Mahmood NR, Wolfe KK, Riggs BJ, Ross CE, McKiernan CA, et al. Characteristics and outcomes of children with coronavirus disease 2019 (COVID-19) infection admitted to US and canadian pediatric intensive care units. JAMA Pediatr. (2020) 174:86873. doi: $10.1001 /$ jamapediatrics.2020.1948

165. Riphagen S, Gomez X, Gonzalez-Martinez C, Wilkinson N, Theocharis P. Hyperinflammatory shock in children during COVID-19 pandemic. Lancet. (2020) 395:1607-8. doi: 10.1016/s0140-6736(20)31094-1

166. Toubiana J, Poirault C, Corsia A, Bajolle F, Fourgeaud J, Angoulvant F, et al. Kawasaki-like multisystem inflammatory syndrome in children during the covid-19 pandemic in Paris, France: prospective observational study. BMJ. (2020) 369:m2094. doi: 10.1136/bmj.m2094

167. Verdoni L, Mazza A, Gervasoni A, Martelli L, Ruggeri M, Ciuffreda M, et al. An outbreak of severe Kawasaki-like disease at the Italian epicentre of the SARS-CoV-2 epidemic: an observational cohort study. Lancet. (2020) 395:1771-8. doi: 10.1016/S0140-6736(20)31103-X

168. Whittaker E, Bamford A, Kenny J, Kaforou M, Jones CE, Shah P, et al. Clinical characteristics of 58 children with a pediatric inflammatory multisystem syndrome temporally associated with SARS-CoV-2. JAMA. (2020) 324:25969. doi: 10.1001/jama.2020.10369

169. Feldstein LR, Rose EB, Horwitz SM, Collins JP, Newhams MM, Son MBF, et al. Multisystem inflammatory syndrome in U.S. children and adolescents. N Engl J Med. (2020) 383:334-46. doi: 10.1056/NEJMoa2021680
170. Godfred-Cato S, Bryant B, Leung J, Oster ME, Conklin L, Abrams J, et al. COVID-19-associated multisystem inflammatory syndrome in children United States, March-July 2020. MMWR Morb Mortal Wkly Rep. (2020) 69:1074-80. doi: 10.15585/mmwr.mm6932e2

171. Feng Z, Bao Y, Yang Y, Zheng Y, Shen K. Severe acute respiratory syndrome coronavirus 2-induced multisystem inflammatory syndrome in children. Pediatr Invest. (2020) 4:257-62. doi: 10.1002/ped4.12225

172. Belhadjer Z, Méot M, Bajolle F, Khraiche D, Legendre A, Abakka S, et al. Acute heart failure in multisystem inflammatory syndrome in children in the context of global SARS-CoV-2 pandemic. Circulation. (2020) 142:42936. doi: 10.1161/CIRCULATIONAHA. 120.048360

173. Henderson LA, Canna SW, Schulert GS, Volpi S, Lee PY, Kernan KF, et al. On the alert for cytokine storm: immunopathology in COVID-19. Arthritis Rheumatol. (2020) 72:1059-63. doi: 10.1002/art.41285

174. Nakra NA, Blumberg DA, Herrera-Guerra A, Lakshminrusimha S. Multisystem inflammatory syndrome in children (MIS-C) following SARS-CoV2 infection: review of clinical presentation, hypothetical pathogenesis, and proposed management. Children. (2020) 7:69. doi: 10.3390/children7070069

175. Jiang L, Tang K, Levin M, Irfan O, Morris SK, Wilson K, et al. COVID-19 and multisystem inflammatory syndrome in children and adolescents. Lancet Infect Dis. (2020) 20:e276-88. doi: 10.1016/S1473-3099(20)30651-4

176. Chiotos K, Hayes M, Kimberlin DW, Jones SB, James SH, Pinninti SG, et al. Multicenter initial guidance on use of antivirals for children with coronavirus disease 2019/severe acute respiratory syndrome coronavirus 2. J Pediatric Infect Dis Soc. (2020) 9:701-15. doi: 10.1093/jpids/piaa045

177. Venturini E, Montagnani C, Garazzino S, Donà D, Pierantoni L, Lo Vecchio A, et al. Treatment of children with COVID-19: position paper of the Italian society of pediatric infectious disease. Ital J Pediatr. (2020) 46:139. doi: 10.1186/s13052-020-00900-w

178. Zhou F, Yu T, Du R, Fan G, Liu Y, Liu Z, et al. Clinical course and risk factors for mortality of adult inpatients with COVID-19 in Wuhan, China: a retrospective cohort study. Lancet. (2020) 395:105462. doi: 10.1016/s0140-6736(20)30566-3

179. Wu Z, McGoogan JM. Characteristics of and important lessons from the coronavirus disease 2019 (COVID-19) outbreak in china: summary of a report of 72314 cases from the Chinese center for disease control and prevention. JAMA. (2020) 323:1239-42. doi: 10.1001/jama. .2648

180. Vestergaard LS, Nielsen J, Richter L, Schmid D, Bustos N, Braeye $T$, et al. Excess all-cause mortality during the COVID19 pandemic in Europe - preliminary pooled estimates from the EuroMOMO network, March to April 2020. Euro surveill. (2020) 25:2001214. doi: 10.2807/1560-7917.ES.2020.25.26.2001214

181. Sudharsanan N, Didzun O, Bärnighausen T, Geldsetzer P. The contribution of the age distribution of cases to COVID-19 case fatality across countries. Ann Intern. Med. (2020) 173:714-20. doi: 10.7326/M20-2973

182. Guo T, Shen Q, Guo W, He W, Li J, Zhang Y, et al. Clinical characteristics of elderly patients with COVID-19 in hunan province, China: a multicenter, retrospective study. Gerontology. (2020) 66:467-75. doi: 10.1159/000508734

183. Smorenberg A, Peters EJG, van Daele PLA, Nossent EJ, Muller M. How does SARS-CoV-2 targets the elderly patients? A review on potential mechanisms increasing disease severity. Eur J Intern Med. (2021) 83:15. doi: 10.1016/j.ejim.2020.11.024

184. Poletti P, Tirani M, Cereda D, Trentini F, Guzzetta G, Sabatino G, et al Probability of symptoms and critical disease after SARS-CoV-2 infection. arXiv:2006.08471v2. (2020)

185. Norman DC. Fever in the elderly. Clin Infect Dis. (2000) 31:14851. doi: $10.1086 / 313896$

186. Mueller AL, McNamara MS, Sinclair DA. Why does COVID-19 disproportionately affect older people? Aging. (2020) 12:995981. doi: 10.18632 /aging. 103344

187. Varadhan R, Yao W, Matteini A, Beamer BA, Xue QL, Yang H, et al. Simple biologically informed inflammatory index of two serum cytokines predicts 10 year all-cause mortality in older adults. J Gerontol A Biol Sci Med Sci. (2014) 69:165-73. doi: 10.1093/gerona/glt023

188. Fulop T, Larbi A, Dupuis G, Le Page A, Frost EH, Cohen AA, et al. Immunosenescence and inflamm-aging as two sides of the same coin: friends or foes? Front Immunol. (2017) 8:1960. doi: 10.3389/fimmu.2017.01960 
189. Crooke SN, Ovsyannikova IG, Poland GA, Kennedy RB. Immunosenescence: a systems-level overview of immune cell biology and strategies for improving vaccine responses. Exp Gerontol. (2019) 124:110632. doi: 10.1016/j.exger.2019.110632

190. Chen Y, Klein SL, Garibaldi BT, Li H, Wu C, Osevala NM, et al. Aging in COVID-19: vulnerability, immunity and intervention. Ageing Res Rev. (2021) 65:101205. doi: 10.1016/j.arr.2020.101205

191. Di Santo SG, Franchini F, Filiputti B, Martone A, Sannino S. The effects of COVID-19 and quarantine measures on the lifestyles and mental health of people over 60 at increased risk of dementia. Front Psychiatry. (2020) 11:578628. doi: 10.3389/fpsyt.2020.578628

192. Schäfer SK, Sopp MR, Schanz CG, Staginnus M, Göritz AS, Michael T. Impact of COVID-19 on public mental health and the buffering effect of a sense of coherence. Psychother Psychosomatics. (2020) 89:38692. doi: $10.1159 / 000510752$

193. Kaddoura M, AlIbrahim M, Hijazi G, Soudani N, Audi A, Alkalamouni H, et al. COVID-19 therapeutic options under investigation. Front Pharmacol. (2020) 11:1196. doi: 10.3389/fphar.2020.01196

194. Inal Jameel M. Decoy ACE2-expressing extracellular vesicles that competitively bind SARS-CoV-2 as a possible COVID-19 therapy. Clin Sci. (2020) 134:1301-4. doi: 10.1042/cs20200623

195. Siemieniuk RAC, Bartoszko JJ, Ge L, Zeraatkar D, Izcovich A, Kum E, et al. Drug treatments for covid-19: living systematic review and network meta-analysis. BMJ. (2020) 370:m2980. doi: 10.1136/bmj.m2980

196. Tikkinen KAO, Malekzadeh R, Schlegel M, Rutanen J, Glasziou P. COVID19 clinical trials: learning from exceptions in the research chaos. Nat Med. (2020) 26:1671-2. doi: 10.1038/s41591-020-1077-z

197. The Recovery Collaborative Group. Dexamethasone in hospitalized patients with Covid-19 - preliminary report. N Eng J Med. (2020) NEJMoa2021436. doi: 10.1056/NEJMoa2021436

198. Savarino A, Boelaert JR, Cassone A, Majori G, Cauda R. Effects of chloroquine on viral infections: an old drug against today's diseases. Lancet Infect Dis. (2003) 3:722-7. doi: 10.1016/S1473-3099(03)00806-5

199. Maisonnasse P, Guedj J, Contreras V, Behillil S, Solas C, Marlin R, et al. Hydroxychloroquine use against SARS-CoV-2 infection in non-human primates. Nature. (2020) 585:584-7. doi: 10.1038/s41586-020-2558-4

200. Wang N, Han S, Liu R, Meng L, He H, Zhang Y, et al. Chloroquine and hydroxychloroquine as ACE2 blockers to inhibit viropexis of 2019-nCoV Spike pseudotyped virus. Phytomedicine. (2020) 79:153333. doi: 10.1016/j.phymed.2020.153333

201. Gautret P, Lagier J-C, Parola P, Hoang VT, Meddeb L, Mailhe M, et al. Hydroxychloroquine and azithromycin as a treatment of COVID-19: results of an open-label non-randomized clinical trial. Int J Antimicrob Agents. (2020) 56:105949. doi: 10.1016/j.ijantimicag.2020.105949

202. Hinton RDM. Letter of Authorization, U.S. Food and Drug Administration. (2020) Available online at: https://www.fda.gov/media/136534/download (accessed September 10, 2020).

203. Boulware DR, Pullen MF, Bangdiwala AS, Pastick KA, Lofgren SM, Okafor EC, et al. A randomized trial of hydroxychloroquine as postexposure prophylaxis for covid-19. N Engl J Med. (2020) 383:517-25. doi: 10.1056/NEJMoa2016638

204. Cavalcanti AB, Zampieri FG, Rosa RG, Azevedo LCP, Veiga VC, Avezum A, et al. Hydroxychloroquine with or without azithromycin in mild-to-moderate covid-19. N Engl J Med. (2020) 383:2041-52. doi: 10.1056/NEJMoa2019014

205. Rosenberg ES, Dufort EM, Udo T, Wilberschied LA, Kumar J, Tesoriero J, et al. Association of treatment with hydroxychloroquine or azithromycin with in-hospital mortality in patients with COVID-19 in New York state. JAMA. (2020) 323:2493-502. doi: 10.1001/jama.2020.8630

206. Arshad S, Kilgore P, Chaudhry ZS, Jacobsen G, Wang DD, Huitsing K, et al. Treatment with hydroxychloroquine, azithromycin, and combination in patients hospitalized with COVID-19. Int J Infect Dis. (2020) 97:396403. doi: 10.1016/j.ijid.2020.06.099

207. Horby P, Mafham M, Linsell L, Bell JL, Staplin N, Emberson JR, et al. Effect of hydroxychloroquine in hospitalized patients with COVID-19: preliminary results from a multi-centre, randomized, controlled trial. $N$ Engl J Med. (2020) 383:2030-40. doi: 10.1056/NEJMoa2022926
208. Ladapo JA, McKinnon JE, McCullough PA, Risch H. Randomized controlled trials of early ambulatory hydroxychloroquine in the prevention of COVID19 infection, hospitalization, and death: meta-analysis. medRxiv. (2020). doi: $10.1101 / 2020.09 .30 .20204693$

209. de Wit E, Feldmann F, Cronin J, Jordan R, Okumura A, Thomas T, et al. Prophylactic and therapeutic remdesivir (GS-5734) treatment in the rhesus macaque model of MERS-CoV infection. Proc Natl Acad Sci USA. (2020) 117:6771-6. doi: 10.1073/pnas.1922083117

210. Pruijssers AJ, George AS, Schäfer A, Leist SR, Gralinksi LE, Dinnon KH III, et al. Remdesivir inhibits SARS-CoV-2 in human lung cells and chimeric SARS-CoV expressing the SARS-CoV-2 RNA polymerase in mice. Cell Rep. (2020) 32:107940. doi: 10.1016/j.celrep.2020.107940

211. Wang Y, Zhang D, Du G, Du R, Zhao J, Jin Y, et al. Remdesivir in adults with severe COVID-19: a randomised, double-blind, placebo-controlled, multicentre trial. Lancet. (2020) 395:156978. doi: 10.1016/S0140-6736(20)31022-9

212. Beigel JH, Tomashek KM, Dodd LE, Mehta AK, Zingman BS, Kalil AC, et al. Remdesivir for the treatment of covid-19 - final report. N Engl J Med. (2020) 383:1813-26. doi: 10.1056/NEJMoa2007764

213. Goldman JD, Lye DCB, Hui DS, Marks KM, Bruno R, Montejano R, et al. Remdesivir for 5 or 10 days in patients with severe covid-19. N Engl J Med. (2020) 383:1827-37. doi: 10.1056/NEJMoa2015301

214. Spinner CD, Gottlieb RL, Criner GJ, Arribas López JR, Cattelan AM, Soriano Viladomiu A, et al. Effect of remdesivir vs standard care on clinical status at 11 days in patients with moderate COVID-19: a randomized clinical trial. JAMA. (2020) 324:1048-57. doi: 10.1001/jama.2020.16349

215. Pan H, Peto R, Henao-Restrepo AM, Preziosi MP, Sathiyamoorthy V, Abdool Karim Q, et al. Repurposed antiviral drugs for COVID-19-interim WHO SOLIDARITY trial results. N Engl J Med. (2020) NEJMoa2023184. doi: 10.1056/NEJMoa2023184

216. Dai W, Zhang B, Jiang X-M, Su H, Li J, Zhao Y, et al. Structure-based design of antiviral drug candidates targeting the SARS-CoV-2 main protease. Science. (2020) 368:eabb4489. doi: 10.1126/science.abb4489

217. Jans DA, Wagstaff KM. Ivermectin as a broad-spectrum host-directed antiviral: the real deal? Cells. (2020) 9:9092100. doi: 10.3390/cells9092100

218. King CR, Tessier TM, Dodge MJ, Weinberg JB, Mymryk JS. Inhibition of human adenovirus replication by the importin $\alpha / \beta 1$ nuclear import inhibitor ivermectin. J Virol. (2020) 94, 00710-20. doi: 10.1128/jvi.00710-20

219. Pooja RM, Chowdhury P. Ivermectin and doxycycline combination as a promising drug candidate against SARS-CoV-2 infection: a computational study. arXiv:2012.00653v1. (2020). Available online at: https://arxiv.org/ftp/ arxiv/papers/2012/2012.00653.pdf

220. Kalfas S, Visvanathan K, Chan K, Drago J. The therapeutic potential of ivermectin for COVID-19: a systematic review of mechanisms and evidence. medRxiv [Preprint]. (2020). doi: 10.1101/2020.11.30.20236570.

221. Chamie J. Real-World Evidence: The Case of Peru. Causality between Ivermectin and COVID-19 Infection Fatality Rate. (2020). Available online at: https://covid19criticalcare.com/wp-content/uploads/2020/12/JUANCHAMIE-REAL-WORLD-EVIDENCE-The-Case- of-Peru.pdf

222. Pandey S, Pathak SK, Pandey A, Salunke AA, Chawla J, Sharma A, et al. Ivermectin in COVID-19: what do we know? Diabetes Metab Syndr. (2020) 14:1921-2. doi: 10.1016/j.dsx.2020.09.027

223. Trial Site. MedinCell's Mission for 'Mass Roll-out' of Ivermectin for COVID19: Early Study Data Points Reveal Promise. Trial Site News. Montpellier (2020). Available online at: https://trialsitenews.com/medincells-missionfor-mass-roll-out-of-ivermectin-for-covid-19-earlystudy-data-pointsreveal-promise/ (accessed January 8, 2021).

224. Vuong W, Khan MB, Fischer C, Arutyunova E, Lamer T, Shields $\mathrm{J}$, et al. Feline coronavirus drug inhibits the main protease of SARS-CoV-2 and blocks virus replication. Nat Commun. (2020) 11:4282. doi: 10.1038/s41467-020-18096-2

225. Shin D, Mukherjee R, Grewe D, Bojkova D, Baek K, Bhattacharya A, et al. Papain-like protease regulates SARS-CoV-2 viral spread and innate immunity. Nature. (2020) 587:657-62. doi: 10.1038/s41586-020-2601-5

226. Ortega JT, Serrano ML, Jastrzebska B. Class A G protein-coupled receptor antagonist famotidine as a therapeutic alternative against SARS-CoV2: an in silico analysis. Biomolecules. (2020) 10:954. doi: 10.3390/biom10060954 
227. Freedberg DE, Conigliaro J, Wang TC, Tracey KJ, Callahan MV, Abrams JA, et al. Famotidine use is associated with improved clinical outcomes in hospitalized COVID-19 patients: a propensity score matched retrospective cohort study. Gastroenterology. (2020) 159:1129-31.e1123. doi: 10.1053/j.gastro.2020.05.053

228. Bestle D, Heindl MR, Limburg $H$, Van Lam van $T$, Pilgram O, Moulton $\mathrm{H}$, et al. TMPRSS2 and furin are both essential for proteolytic activation of SARS-CoV-2 in human airway cells. Life Sci Alliance. (2020) 3:e202000786. doi: 10.26508/lsa.202000786

229. Cheng Y-W, Chao T-L, Li C-L, Chiu M-F, Kao H-C, Wang S$\mathrm{H}$, et al. Furin inhibitors block SARS-CoV-2 spike protein cleavage to suppress virus production and cytopathic effects. Cell Rep. (2020) 33:108254. doi: 10.1016/j.celrep.2020.108254

230. Coutard B, Valle C, de Lamballerie X, Canard B, Seidah NG, Decroly E. The spike glycoprotein of the new coronavirus 2019-nCoV contains a furinlike cleavage site absent in $\mathrm{CoV}$ of the same clade. Antiviral Res. (2020) 176:104742. doi: 10.1016/j.antiviral.2020.104742

231. Hempel T, Raich L, Olsson S, Azouz NP, Klingler AM, Hoffmann M, et al. Molecular mechanism of inhibiting the SARS-CoV-2 cell entry facilitator TMPRSS2 with camostat and nafamostat. Chem Sci. (2021) 12:983-92. doi: 10.1039/D0SC05064D

232. Jones BE, Brown-Augsburger PL, Corbett KS, Westendorf K, Davies J, Cujec TP, et al. LY-CoV555, a rapidly isolated potent neutralizing antibody, provides protection in a non-human primate model of SARS-CoV-2 infection. bioRxiv [preprint]. (2020) doi: 10.1101/2020.09.30.318972v3

233. Baum A, Fulton BO, Wloga E, Copin R, Pascal KE, Russo V, et al. Antibody cocktail to SARS-CoV-2 spike protein prevents rapid mutational escape seen with individual antibodies. Science. (2020) 369:1014-8. doi: 10.1126/science.abd0831

234. Weinreich DM, Sivapalasingam S, Norton T, Ali S, Gao H, Bhore R, et al. REGN-COV2, a neutralizing antibody cocktail, in outpatients with covid-19. N Engl J Med. (2020) 384:238-51. doi: 10.1056/NEJMoa2035002

235. Trial Site. Eli Lilly's Monoclonal Antibody Takes a Hit: Bamlanivimab Fails Part of ACTIV-3 Trial: Greater Challenges Ahead? (2021) Available online at: https://trialsitenews.com/eli-lillys-monoclonal-antibody-takesa-hit-bamlanivimab-fails-part-of-activ-3-trial-greater-challenges-ahead/ (accessed January 06, 2021).

236. doubtGOV. UK. (2020) "Oxford University/AstraZeneca COVID-19 vaccine approved".

237. Doherty M, Buchy P, Standaert B, Giaquinto C, Prado- Cohrs D. Vaccine impact: benefits for human health. Vaccine. (2016) 34:670714. doi: 10.1016/j.vaccine.2016.10.025

238. Corum J, Wee S, Zimmer C. Coronavirus Vaccine Tracker. New York, NY: The New York Times. (2020). Available online at: https://www.nytimes. com/interactive/2020/science/coronavirus-vaccine-tracker.html (accessed October 8, 2020)

239. US Department of Health and Human Services. Fact Sheet: Explaining Operation Warp Speed What's the Goal? (2020) Available online at: https:// www.hhs.gov/coronavirus/explaining-operation-warp-speed/index.html (accessed October 8, 2020).

240. Butler D. Billion-dollar project aims to prep vaccines before epidemics hit. Nature. (2017) 541:444-5. doi: 10.1038/nature.2017.21329 Available online at: https://www.nature.com/news/polopoly_fs/1.21329!/menu/ main/topColumns/topLeftColumn/pdf/nature.2017.21329.pdf?origin=ppub (accessed June 8, 2020).

241. Krammer F. SARS-CoV-2 vaccines in development. Nature. (2020) 586:51627. doi: $10.1038 / \mathrm{s} 41586-020-2798-3$

242. Sharma O, Sultan AA, Ding H, Triggle CR. A review of the progress and challenges of developing a vaccine for COVID-19. Front Immunol. (2020) 11:585354. doi: 10.3389/fimmu.2020.585354

243. Keech C, Albert G, Cho I, Robertson A, Reed P, Neal S, et al. Phase 1-2 trial of a SARS-CoV-2 recombinant spike protein nanoparticle vaccine. $\mathrm{N} \mathrm{Engl} \mathrm{J}$ Med. (2020) 383:2320-32. doi: 10.1056/NEJMoa2026920

244. Xia S, Duan K, Zhang Y, Zhao D, Zhang H, Xie Z, et al. Effect of an inactivated vaccine against SARS-CoV-2 on safety and immunogenicity outcomes: interim analysis of 2 randomized clinical trials. JAMA. (2020) 324:951-60. doi: 10.1001/jama.2020.15543
245. Folegatti PM, Bittaye M, Flaxman A, Lopez FR, Bellamy D, Kupke A, et al. Safety and immunogenicity of a candidate middle east respiratory syndrome coronavirus viral-vectored vaccine: a dose-escalation, open-label, non-randomised, uncontrolled, phase 1 trial. Lancet Infect Dis. (2020) 20:816-26. doi: 10.1016/S1473-3099(20)30160-2

246. Ramasamy MN, Minassian AM, Ewer KJ, Flaxman AL, Folegatti PM, Owens DR, et al. Safety and immunogenicity of ChAdOx1 $\mathrm{nCoV}-19$ vaccine administered in a prime-boost regimen in young and old adults (COV002): a single-blind, randomised, controlled, phase 2/3 trial. Lancet. 2021 396:197993. doi: 10.1016/S0140-6736(20)32466-1

247. Voysey M, Clemens SAC, Madhi SA, Weckx LY, Folegatti PM, Aley PK, et al. Safety and efficacy of the ChAdOx1 nCoV-19 vaccine (AZD1222) against SARS-CoV-2: an interim analysis of four randomised controlled trials in Brazil, South Africa, and the UK. The Lancet. (2020) 397:99-111. doi: 10.1016/S0140-6736(20)32661-1

248. Zhu F-C, Guan X-H, Li Y-H, Huang J-Y, Jiang T, Hou L-H, et al Immunogenicity and safety of a recombinant adenovirus type-5-vectored COVID-19 vaccine in healthy adults aged 18 years or older: a randomised, double-blind, placebo-controlled, phase 2 trial. Lancet. (2020) 396:47988. doi: 10.1016/S0140-6736(20)31605-6

249. Logunov DY, Dolzhikova IV, Zubkova OV, Tukhvatullin AI, Shcheblyakov DV, Dzharullaeva AS, et al. Safety and immunogenicity of an rAd26 and rAd5 vector-based heterologous prime-boost COVID-19 vaccine in two formulations: two open, non-randomised phase $1 / 2$ studies from Russia. Lancet. (2020) 396:887-97. doi: 10.1016/S0140-6736(20) 31866-3

250. Anderson EJ, Rouphael NG, Widge AT, Jackson LA, Roberts PC, Makhene $M$, et al. Safety and immunogenicity of SARS-CoV2 mRNA-1273 vaccine in older adults. $N$ Engl J Med. (2020) 283:2427-38. doi: 10.1056/NEJMoa2028436

251. Baden LR, El Sahly HM, Essink B, Kotloff K, Frey S, Novak R, et al. Efficacy and safety of the mRNA-1273 SARS-CoV-2 Vaccine. N Engl J Med. (2021) 384:403-16. doi: 10.1056/NEJMoa2035389

252. Mulligan MJ, Lyke KE, Kitchin N, Absalon J, Gurtman A, Lockhart S, et al. Phase I/II study of COVID-19 RNA vaccine BNT162b1 in adults. Nature. (2020) 586:589-93. doi: 10.1038/s41586-020-2639-4

253. Polack FP, Thomas SJ, Kitchin N, Absalon J, Gurtman A, Lockhart S, et al. Safety and efficacy of the BNT162b2 mRNA covid-19 vaccine. N Engl J Med. (2020) 383:2603-15. doi: 10.1056/NEJMoa2034577

254. Rauch S, Jasny E, Schmidt KE, Petsch B. New vaccine technologies to combat outbreak situations. Front. Immunol. (2018) 9:1963. doi: 10.3389/fimmu.2018.01963

255. Fausther-Bovendo H, Kobinger GP. Pre-existing immunity against Ad vectors. Hum Vaccines Immunother. (2014) 10:287584. doi: $10.4161 /$ hv. 29594

256. Abbott A. Researchers highlight 'questionable' data in Russian coronavirus vaccine trial results. Nature. (2020) 585:493. doi: 10.1038/d41586-020-02619-4

257. Cohen J. Amid the cheering, some vaccines face questions. Science. (2020) 370:1151. doi: 10.1126/science.370.6521.1151

258. Knoll MD, Wonodi C. Oxford-AstraZeneca COVID-19 vaccine efficacy. Lancet. (2021) 397:72-4. doi: 10.1016/S0140-6736(20)32623-4

259. Balfour H. AstraZeneca to Test Combination of AZD1222 and Sputnik $V$ Vaccines. (2020) Available online at: https://www. europeanpharmaceuticalreview.com/news/136683/astrazeneca-to-testcombination-of-azd1222-and-sputnik-v-vaccines/ (accessed December 3, 2020).

260. Zhang Y, Zeng G, Pan H, Li C, Hu Y, Chu K, et al. Safety, tolerability, and immunogenicity of an inactivated SARS-CoV-2 vaccine in healthy adults aged 18-59 years: a randomised, double-blind, placebocontrolled, phase 1/2 clinical trial. Lancet Infect Dis. (2021) 21:181-92. doi: 10.1016/S1473-3099(20)30843-4

261. Mcgregor G. China Drugmaker Fact-Checks Claim That Its Leading COVID Vaccine Is 97\% Effective. New York, NY: Fortune (2020). Available online at: https://fortune.com/2020/12/08/china-covid-vaccinesinovac-efficacy-seroconversion-rate-pfizer-moderna/ (accessed December $8,2020)$. 
262. Cyranoski D. Arab nations first to approve Chinese COVID vaccine - despite lack of public data. Nature. (2020) 588:548. doi: 10.1038/d41586-020-03563-z

263. National Institutes of Health. Phase 3 Trial of Novavax Investigational COVID-19 Vaccine Opens. Bethesda: U.S. Department of Health \& Human Services. (2020). Available online at: https://www.nih.gov/news-events/ news-releases/phase-3-trial-novavax-investigational-covid-19-vaccineopens (accessed January 8, 2021).

264. Pardi N, Hogan MJ, Porter FW, Weissman D. mRNA vaccines a new era in vaccinology. Nat Rev Drug Discov. (2018) 17:26179. doi: 10.1038/nrd.2017.243

265. Maruggi G, Zhang C, Li J, Ulmer JB, Yu D. mRNA as a transformative technology for vaccine development to control infectious diseases. Mol Ther. (2019) 27:757-72. doi: 10.1016/j.ymthe.2019.01.020

266. Abbasi J. COVID-19 and mRNA vaccines-first large test for a new approach. JAMA. (2020) 324:1125-7. doi: 10.1001/jama.2020.16866

267. Jackson LA, Anderson EJ, Rouphael NG, Roberts PC, Makhene M, Coler RN, et al. An mRNA vaccine against SARS-CoV-2 - preliminary report. $N$ Engl J Med. (2020) 383:1920-31. doi: 10.1056/NEJMoa2022483

268. Callaway E. What Pfizer's landmark COVID vaccine results mean for the pandemic. Nature. (2020). doi: 10.1038/d41586-020-03166-8. Available online at: https://www.nature.com/articles/d41586-020-03166-8 (accessed November 10, 2020).

269. Walsh EE, Frenck R, Falsey AR, Kitchin N, Absalon J, Gurtman A, et al. RNAbased COVID-19 vaccine BNT162b2 selected for a pivotal efficacy study. medRxiv. (2020) 2020.08.17.20176651. doi: 10.1101/2020.08.17.20176651

270. Cairns E. Moderna Prices its Covid-19 Vaccine in the Luxury Range. Evaluate Advantage, London, United Kingdom. (2020) Available online at: https:// www.evaluate.com/vantage/articles/news/snippets/moderna-prices-itscovid-19-vaccine-luxury-range (accessed October 10, 2020).

271. de Vrieze J. Suspicions grow that nanoparticles in Pfizer's COVID-19 vaccine trigger rare allergic reactions. Science. (2020). doi: 10.1126/science.abg2359

272. O'Hare R. Imperial's COVID-19 Vaccine Moves to Next Phase. London: Imperial College London. (2020). Avaialble online at: https://www. imperial.ac.uk/news/199993/imperials-covid-19-vaccine-moves-nextphase/ (accessed October 10, 2020).

273. Potter C. Zero COVID-19 Deaths in Vietnam. (2020) Available online at: https://www.outbreakobservatory.org/outbreakthursday-1/7/9/2020/zerocovid-19-deaths-in-vietnam (accessed October 10, 2020).

274. Cheng H-Y, Jian S-W, Liu D-P, Ng T-C, Huang W-T, Lin H-H, et al. Contact tracing assessment of COVID-19 transmission dynamics in taiwan and risk at different exposure periods before and after symptom onset. JAMA Intern Med. (2020) 180:1156-63. doi: 10.1001/jamainternmed.2020.2020

275. Haug N, Geyrhofer L, Londei A, Dervic E, Desvars-Larrive $\mathrm{A}$, Loreto $\mathrm{V}$, et al. Ranking the effectiveness of worldwide COVID-19 government interventions. Nat Hum Behav. (2020) 4:1303-12. doi: 10.1038/s41562-020-01009-0

276. Yang W, Shaff J, Shaman J. COVID-19 transmission dynamics and effectiveness of public health interventions in New York city during the 2020 spring pandemic wave. medRxiv. (2020). doi: 10.1101/2020.09.08.20 190710

277. Han E, Tan MMJ, Turk E, Sridhar D, Leung GM, Shibuya K, et al. Lessons learnt from easing COVID-19 restrictions: an analysis of countries and regions in Asia Pacific and Europe. Lancet. (2020) 396:152534. doi: 10.1016/S0140-6736(20)32007-9
278. Feng S, Shen C, Xia N, Song W, Fan M, Cowling BJ. Rational use of face masks in the COVID-19 pandemic. Lancet Respir Med. (2020) 8:4346. doi: 10.1016/S2213-2600(20)30134-X

279. Chaabna K, Doraiswamy S, Mamtani R, Cheema S. Facemask use in community settings to prevent respiratory infection transmission: A rapid review and meta-analysis. Int J Infect Dis. (2020) 104:198-206. doi: 10.1016/j.ijid.2020.09.1434

280. Gandhi M, Rutherford GW. Facial masking for covid-19 - potential for "Variolation" as we await a vaccine. N Engl J Med. (2020) 383:e101. doi: 10.1056/NEJMp2026913

281. Marshall M. The lasting misery of coronavirus long-haulers. Nature. (2020) 585:339-41. doi: 10.1038/d41586-020-02598-6

282. Haseltine WA. What COVID-19 Reinfection Means for Vaccines. Scientific American. (2020) Available online at: https://www.scientificamerican. com/article/what-covid-19-reinfection-means-for-vaccines/ (accessed November 10, 2020).

283. Bos LDJ, Brodie D, Calfee CS. Severe COVID-19 infections-knowledge gained and remaining questions. JAMA Intern Med. (2020) 181:911. doi: 10.1001/jamainternmed.2020.6047

284. Vogel G, Couzin-Frankel J. As COVID-19 soars in many communities, schools attempt to find ways through the crisis. Science. (2020). doi: $10.1126 /$ science.abf7779

285. Volz E, Mishra W, Chand M, Jeffrey C, Barrett JC, Johnson R, et al. Transmission of SARS-CoV-2 Lineage B.1.1.7 in England: insights from linking epidemiological and genetic data. medRxiv [preprint]. (2021). doi: $10.1101 / 2020.12 .30 .20249034$

286. IHME Foundations. Despite Vaccinations, COVID-19 Death Toll Likely to Increase Into April. (2020) Available online at: http://www.healthdata.org/ news-release/despite-vaccinations-covid-19-death-toll-likely-increaseapril (accessed January 08, 2021).

287. Vidal J. 'Why Wait for It?' How to Predict a Pandemic. London: The Guardian. (2020). Available online at: https://www.theguardian.com/globaldevelopment/2020/sep/16/how-to-predict-a-pandemic-worlds-mostdangerous- viruses?fbclid=IwAR2m5zCZsLs5cj3HYxs1UrWUtF8BeVRVz8HLqyE-Sd3exvC5XUovXOU698 (accessed September 17, 2020).

288. Gibb R, Redding DW, Chin KQ, Donnelly CA, Blackburn TM, Newbold $\mathrm{T}$, et al. Zoonotic host diversity increases in human-dominated ecosystems. Nature. (2020) 584:398-402. doi: 10.1038/s41586-020-2562-8

289. The Trinity Challenge (2020). Available online at: https://thetrinitychallenge. org/ (accessed October 02, 2020).

290. Morens DM, Fauci AS. Emerging pandemic diseases: how we got to COVID19. Cell. (2020) 182:1077-92. doi: 10.1016/j.cell.2020.08.021

Conflict of Interest: The authors declare that the research was conducted in the absence of any commercial or financial relationships that could be construed as a potential conflict of interest.

Copyright (c) 2021 Triggle, Bansal, Ding, Islam, Farag, Hadi and Sultan. This is an open-access article distributed under the terms of the Creative Commons Attribution License (CC BY). The use, distribution or reproduction in other forums is permitted, provided the original author(s) and the copyright owner(s) are credited and that the original publication in this journal is cited, in accordance with accepted academic practice. No use, distribution or reproduction is permitted which does not comply with these terms. 